University of Louisville

ThinkIR: The University of Louisville's Institutional Repository

Electronic Theses and Dissertations

$12-2007$

\title{
The changes of fructos-2,6-bisphosphate level in transgenic mice causing cardiomyopathy.
}

Jianxun Wang 1969-

University of Louisville

Follow this and additional works at: https://ir.library.louisville.edu/etd

\section{Recommended Citation}

Wang, Jianxun 1969-, "The changes of fructos-2,6-bisphosphate level in transgenic mice causing cardiomyopathy." (2007). Electronic Theses and Dissertations. Paper 1514.

https://doi.org/10.18297/etd/1514

This Master's Thesis is brought to you for free and open access by ThinkIR: The University of Louisville's Institutional Repository. It has been accepted for inclusion in Electronic Theses and Dissertations by an authorized administrator of ThinkIR: The University of Louisville's Institutional Repository. This title appears here courtesy of the author, who has retained all other copyrights. For more information, please contact thinkir@louisville.edu. 


\title{
THE CHANGES OF FRUCTOS-2,6-BISPHOSPHATE LEVEL IN TRANSGENIC MICE CAUSING CARDIOMYOPATHY
}

\author{
By
}

Jianxun Wang

M.S. in Biology Genetics, Sun Yat-sen University, China

A Thesis Submitted to the Faculty of the Graduate School of the University of Louisville in Partial Fulfillment of the Requirements for the Degree of

\author{
Master of Science \\ Pharmacology and Toxicology \\ Department of Pharmacology and Toxicology \\ University of Louisville \\ Louisville, KY
}

December 2007 
THE CHANGES OF FRUCTOSE-2, 6-BISPHOSPHATE LEVEL IN TRANSGENIC MICE CAUSING CARDIOMYOPATHY

\section{By}

Jianxun Wang

M.S. in Biology Genetics, Sun Yat-sen University, China

A Thesis Approved on November, 2007

by the Following Thesis Committee

Dr. Paul N. Epstein, Mentor and Thesis Director

Dr. David W. Hein

Dr. William M. Pierce Jr.

Dr. Frederick W. Benz

Dr. Stephen J. Winters 


\section{ACKNOWLEDGEMENTS}

I would like to thank my mentor, Dr. Paul N. Epstein, for his guidance and patience on me. I would also like to thank the other committee members, Dr. David W. Hein, Dr. William M. Pierce, Dr. Frederick W. Benz and Dr. Stephen J. Winters, for their valuable suggestions and assistance of this project. I would also like to thank my wife Qianwen Wang for her support. 


\begin{abstract}
THE CHANGES OF FRUCTOSE-2,6-BISPHOSPHATE LEVEL IN TRANSGENIC MICE CAUSING CARDIOMYOPATHY
\end{abstract}

\author{
Jiarıxun Wang
}

June 19, 2007

Heart failure is recognized as a major cause of death among diabetics. In type I and II diabetes, glucose uptake, glycolysis and pyruvate oxidation are impaired, and fatty acid utilization increases. These alterations in metabolism contribute toward cardiac contractile function. There is a gap in our understanding on how alterations in glycolytic metabolite fructose-2,6-bisphosphate $\left(F-2,6-P_{2}\right)$ affects cardiac dysfunction. Two cardiac-specific overexpression of PFK-2 (phosphofructose kinase-2) transgenic models were used to investigate the role of altered metabolism by $\mathrm{F}-2,6-\mathrm{P}_{2}$ in provoking cardiomyopathy. One model is with the PFK-2 kinase active and phosphatase inactive enzyme called MK and another model is the PFK-2 kinase inactive and phosphatase active enzyme called $\mathrm{Mb}$. The effect of PFK2 transgenes was evaluated by Langendorff -perfused heart in vitro. Cardiomyopathy was assessed by measurement of heart to body weight ratio and cardiac histology. The study shows that changes in $\mathrm{F}-2,6-\mathrm{P}_{2}$ level could induce cardiac hypertrophy and fibrosis and cause cardiac dysfunction, and may be important to development of diabetic cardiomyopathy. 


\section{TABLE OF CONTENTS}

PAGE

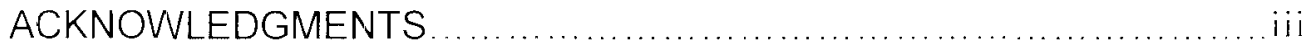

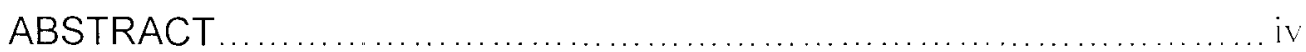

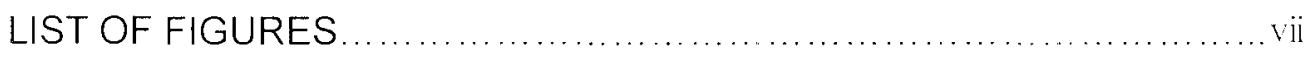

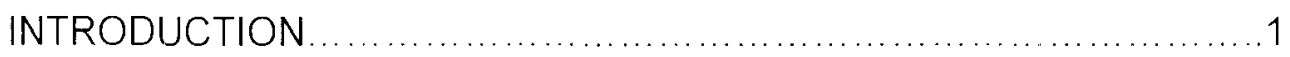

METHODS AND MATERIAS ....................................... 13

1. Development of Transgenic Mice...................................... 13

2. Analysis of Fructose-2,6-Bisphosphate Content in Transgenic Mice.....14

3. Cardiac Perfusion................................................ 14

4. Measurement of Glycolysis And Lactate Production .................... 15

5. Isolation Of Adult Mouse Ventricular Myocytes ......................... 15

6. Culture Of Adult Mouse Cardiac Myocytes............................ 17

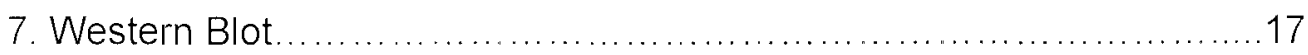

8. Phenyephrine administration by pump implantation.................... 18

9. Histological Study .............................................. 18

10. Statistical Analysis ............................................... 19

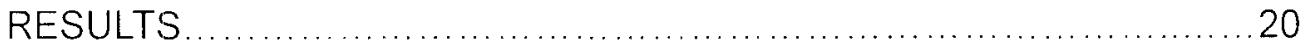

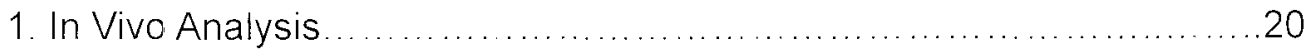

2. Langendorff Perfused Heart Data .................................. 21

3. In Vitro Analysis .................................................... 31

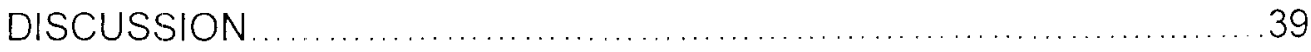


REFERENCES

52

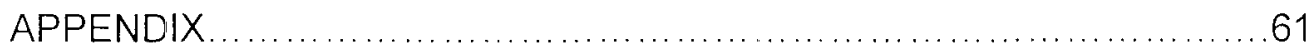

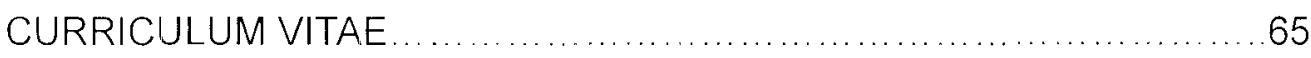




\section{LIST OF FIGURES}

FIGURE

PAGE

1. A balance between metabolites of glucose and fat acids in the healthy cardiomyocyte. .8

2. Randle cycle

3. The signal pathways induced by the intracellular accumulation of fatty acids 11

4. The content of F-2,6- $\mathrm{P}_{2}$ in FVB, Mk and $\mathrm{Mb} 7$ mice 22

5. The ratio of heart to body weight in FVB control, Mb and Mk mice.......23

6. Collagen accumulation in FVB and Mb hearts........................24

7. Collagen accumulation in FVB and Mk hearts ............................ 25

8. Survival curves of $\mathrm{Mb}, \mathrm{Mk}$ and FVB mice with treatment of phenylephrine for 28 days 26

9. HE staining on $\mathrm{Mb}, \mathrm{Mk}$ and FVB control hearts after being treated with phenylephrine for 3 days. 27

10. Histology of FVB hearts with phenylephrine and saline treatment..... 28

11. Cardiac glycolysis and stimulatory effect of insulin were reduced in $\mathrm{Mb}$ mice. 30

12. Effect of kinase active PFK-2 on glycolysis with or without

$0.4 \mathrm{mM}$ palmitate before and after addition of $200 \mu \mathrm{U} / \mathrm{ml}$ insulin 33 
13. The effect of palmitate on glycolysis in FVB control and Mk mice. 34

14. P-AKT and P-IR signals in cultured cardiomyocytes stimulated by insulin. . 35

15. Replot of P-IR and P-AKT from figure 14. 36

16. P-4EBP1 in cultured cardiomyocytes challenged with insulin. 37

17. P-GSK-3b in cultured cardiomyocytes challenged with insulin. 38 


\section{INTRODUCTION}

\section{Significance and Background}

Diabetes mellitus is the world's fastest growing disease. Almost 20.8 million children and adults in the United States have diabetes. Type 1 diabetes can not produce insulin due to pancreatic $\beta$-cell dysfunction and type 2 diabetes can not properly use irisulin due to insulin resistance and pancreatic $\beta$-cell dysfunction. An association between diabetes and cardiac disease was first recognized in the late 1800s. More recently, the Framingham Heart Study ${ }^{1,2}$ provided conclusive evidence of the role of diabetes in heart failure: in a prospective study of 5,000 individuals, the risk of heart failure was increased in diabetic men and women by two- and five-fold respectively and heart failure is now recognized as a major cause of death among diabetics ${ }^{3}$. Diabetic patients usually exhibit diabetic cardiomyopathy, leading to congestive heart failure. Diabetic cardiomyopathy is characterized by impaired cardiac contractility and poor myocardial performance without vascular or valvular disease ${ }^{4}$. Several metabolic complications which are involved in diabetic cardiomyopathy are common to both types 1 and 2 diabetes. For example, hyperglycemia and elevated free fatty acids (FFA) are present in type 1 and 2 diabetes. Although the time course of developing ventricular dysfunction may be different, the cardiac consequences of both types of diabetes are similar. However, the 
mechanisms by which diabetic cardiomyopathy develops is still unclear. A better understanding of cardiomyopathy development during diabetes can provide information for the treatment of cardiomyopathy.

Under normal conditions, fatty acids provide $70 \%$ and glucose and lactate provide $30 \%$ energy for heart ${ }^{5,6.7}$. (see figure 1) In pathophysiologic conditions, such as cardiomyopathy, the heart can rapidly switch its substrates between glucose and fatty acids to ensure continuous ATP generation for maintaining heart function $8,9,10,11,12,13,14$. However, this transition has also been associated with deleterious consequences. In type I and type II diabetes mellitus, glucose uptake, glycolysis and pyruvate oxidation are impaired, and fatty acid utilization increases. This alteration in metabolism contributes toward cardiac contractile dysfunction ${ }^{15}$, other factors contributing to diabetic cardiomyopathy, such as changes of $\mathrm{Ca}^{2+}$ homeostasis, decreased cardiac efficiency, liptoxicity and myocardial mitochondrial damage, have also been linked to alterations in myocardial metabolism. These changes in cardiac metabolism are early events and precede the development of cardiomyopathy ${ }^{16}$. Furthermore, normalizing cardiac metabolism in diabetic animals can reverse the development of cardiomyopathy ${ }^{17,18,19}$. Therefore, a proper balance of cardiac metabolism is a key factor to maintaining a healthy heart. Disruption of the balance of myocardial metabolism by high glucose and/or by hyperlipidemia could result in cardiomyopathy.

There is a gap in our understanding of how alterations in the glycolytic metabolite, fructose-2,6--biphosphate $\left(\mathrm{F}-2,6-\mathrm{P}_{2}\right)$, affects cardiac function. $\mathrm{F}-2,6-\mathrm{P}_{2}$ is a key regulator of phosphofructose kinase-1 (PFK-1), 
one of the rate-limiting steps of glycolysis ( see figure 1). In hepatic cells, increased $\mathrm{F}-2,6-\mathrm{P}_{2}$ can also modify expression of genes involved in carbohydrate metabolism, increasing expression of glucokinase and inhibiting expression of glucose-6-phosphatase, meanwhile the expression of two key lipogenic enzymes, acetyl-CoA carboxylase and fatty acid synthetase, is reduced. ${ }^{47}$ Therefore, changes in F-2,6-P levels in the heart may disturb the balance of cardiac metabolism.

\section{Glucose uptake and utilization}

In the heart, cardiac glucose uptake is driven by a glucose gradient and is dependent on the density of sarcolemmal glucose transporters such as Glut1 and Glut4. Under basal conditions without insulin stimulation, Glut4 is located in an intracellular pool and Glut1 is primarily located on the sarcolemma membrane, therefore, Glut1 transporter regulates basal glucose uptake. Upon activation by insulin, however, Glut4 will translocate to the cell membrane to transport glucose $e^{20,21,22}$, as a major contributor for glucose uptake. After glucose enters the cardiomyoctye glycolysis occurs. Glycolysis is controlled by a network of enzymes including hexokinase, PFK-1 and PFK-2. After glycolysis, pyruvate can enter mitochondria for oxidation. Glycolysis is far more complicated than just breaking down glucose. ATP derived from glycolysis seems to have a preferential role in maintaining normal conductance for calcium, potassium and sodium ions in the cell membrane $23,24,25$. In isolated perfused hearts, increased utilization of glucose can decrease ischemic damage while decreased utilization of glucose tends to sensitize the heart to ischemia $^{50}$.

The glycolytic rate is lower in diabetics. A low rate of glycolysis will 
impact heart function, even leading to cardiomyopathy ${ }^{15}$. F-2,6- $P_{2}$ is a key regulator of PFK-1, one of the rate limiting steps of glycolysis. Decreased $\mathrm{F}-2,6-\mathrm{P}_{2}$ mimics the situation in diabetes and will reduce the glycolytic rate. In diabetic states, hepatic F-2,6- $\mathrm{P}_{2}$ levels are low due to insulin deficiency, or relatively low due to insulin resistance ${ }^{49}$. If this low level of hepatic F-2,6-P is raised, however, blood glucose levels could be reduced, and many of the metabolic consequences of type 2 diabetes could be ameliorated ${ }^{26.27}$. Proposed mechanisms for functional recovery by increased $\mathrm{F}-2,6-\mathrm{P}_{2}$ are that $F-2,6-P_{2}$ increases AKT phosphorylation, favors glycolysis and suppresses gluconeogenesis through allosteric activation of PFK $1^{28}$. Therefore, decreased $\mathrm{F}-2,6-\mathrm{P}_{2}$, leading to reduction of glycolysis and ATP, will decrease ion channel activity on the cardiomyocyte membrane and reduce membrane potential. We therefore hypothesize that decreased $\mathrm{F}-2,6-\mathrm{P}_{2}$ in the $\mathrm{Mb}$ transgenic model mouse will result in cardiomyopathy.

Hyperglycemia can provoke glucotoxicity, causing cardiac tissue injury due to excess production of reactive oxygen species (ROS), leading to release of cytochrome $\mathrm{C}$ and activation of Poly (ADP-ribose) polymerase-1 (PARP) ${ }^{29}$. PARP, through inhibition of glyceraldehyde phosphate dehydrogenase (GAPDH), diverts glucose from glycolytic pathways to other pathways, including polyol and hexosamine pathway flux ${ }^{30}$. In the polyol pathway the cell will be depleted of NADPH and GSH, and oxidative stress will increase. In the hexosamine pathway, activities of some transcriptional factors such as SP1 will be affected and gene expression profiles will be altered. Increased $\mathrm{F}-2,6-\mathrm{P}_{2}$ can increase glycolytic rate and decrease intracellular glucose levels. In the MK transgenic mouse, this decrease of intracellular 
glucose could facilitate glucose uptake by the transporter Glut1 using the energy of the glucose gradient potential mimicking the high glucose level of diabetes, exhibiting glucotoxicity. We hypothesize that excess $F-2,6-P_{2}$, through multiple pathways such as the polyol and hexosamine pathways, contributes to the development of cardiomyopathy.

\section{Fatty acid uptake and utilization}

Three fatty acid (FA) transport proteins have been identified In the heart,: CD36, FA transport protein (FATP) and FA binding protein plasma membrane $(F A B P p m)^{31}$. Once the FA enters cardiomyocytes, the FA will be esterfied by acyl-CoA synthase (ACS), the fatty acyl-.CoA can then be transported into mitochondria for oxidation or stored as triglycerides $(\mathrm{Tg})$. In normal heart, there is a balance between lipogenesis and lipolysis to control intracellular $\mathrm{Tg}$ level ${ }^{32}$. If $\mathrm{FA}$ supply is far more than cellular oxidative capacity, $\mathrm{Tg}$ can accumulate and lipotoxictiy follows. For example, transgenic mice overexpressing cardiac ACS, FATP or LPL (lipoprotein lipase) demonstrated that increased FA uptake and utilization of FA and/or lipid accumulation correlated well with contractile dysfunction. ${ }^{33,34,35}$ In human diabetic patients, increased FA utilization is associated with augmented cardiac oxygen consumption and reduced cardiac efficiency. Reduction of cardiac efficiency and increased oxygen demand makes the heart especially vulnerable to damage following increased workloads or ischemia. ${ }^{15}$ Accumulation of FA leads to augmented intracellular FA derivatives, such as fatty acyl-CoA, diacylglycerol and ceramide. ${ }^{36.37 .38}$ These FA metabolites activate a serine kinase cascade which phosphorylates serine of insulin receptor substrate (IRS). Serine phosphorylation of IRS-1 reduces tyrosine 
phosphorylation of IRS-1, resulting in insulin resistance. ${ }^{39}, 40,41,42,43$ Therefore, decreased $\mathrm{F}-2,6-\mathrm{P}_{2}$ will reduce glycolysis and glucose oxidation and potentially stimulate cardiomocytes to transport more fatty acids to compensate for the deficiency of ATP, leading to accumulation of FA metabolites and resulting in cardiomyopathy (see figure 3).

\section{Cross talk between fatty acid and glucose utilization}

Healthy hearts derive most of their energy from free fatty acids and only a small proportion from circulating glucose. However, diabetic hearts use more fat and less glucose than normal hearts ${ }^{44}$. For example, FA oxidation accounts for $93 \%$ of calculated ATP production in diabetic hearts compared with $64 \%$ in control hearts. Glycolysis accounts for only $4 \%$ of ATP production in diabetic hearts relative to $11 \%$ in normal hearts, and glucose oxidation accounts for only $3 \%$ of ATP production compared with $25 \%$ in control hearts. ${ }^{45}$ In contrast to diabetic hearts, there is an increase in cardiac glucose usage and a reduction in fat consumption after a myocardial infarction. Overexpression of LPL in the heart accelerates FA uptake, conversely, tissue specific knockout of LPL causes heart to prefer glucose. The presence of glucose also can reduce fatty acid metabolism, probably by increasing intracellular level of malonyl-CoA. ( see figure 2). These alterations of cardiac metabolism are important causative factors in the development of cardiomyopathy, as shown in the perfused hearts from leptin receptor deficient $(\mathrm{db} / \mathrm{db})$ mice and transgenic $\mathrm{db} / \mathrm{db}-\mathrm{h}$ GLUt4 mice which overexpress Glut4. Reduced fasting hyperglycemia and improved glucose disposal after an oral glucose challenge in $\mathrm{db} / \mathrm{db}$-Glut4 mice was observed when compared to $\mathrm{db} / \mathrm{db}$ mice ${ }^{48}$ while reduced contractile performance in $\mathrm{db} / \mathrm{db}$ mice was also 
completely normalized in $\mathrm{db} / \mathrm{db}$-Glut4 mice. ${ }^{45}$

Some studies show that activation of cardiac PPAR-a not only favors FA oxidation but also inhibits glucose uptake and utilization, leading to augmented susceptibility to ischemic damage. Knockout of cardiac PPAR- $\alpha$ prevents suppression of GLUt4 expression and glucose uptake by elevated plasma FA and improves myocardial recovery from ischemia, ${ }^{46}$ the mechanisms that explain how changes of cardiac metabolism are involved in diabetic cardiomyopathy are still unclear. We hypothesize that decreased $\mathrm{F}-2,6-\mathrm{P}_{2}$ will shift the cardiac metabolite from glucose to FA utilization and increased $\mathrm{F}-2,6-\mathrm{P}_{2}$ shift the cardiac metabolite from $\mathrm{FA}$ to glucose utilization. The shift between glucose and fatty acid utilization may cause abnormal cardiac function e.g. heart hypertrophy, heart failure and cardiomyopathy. 


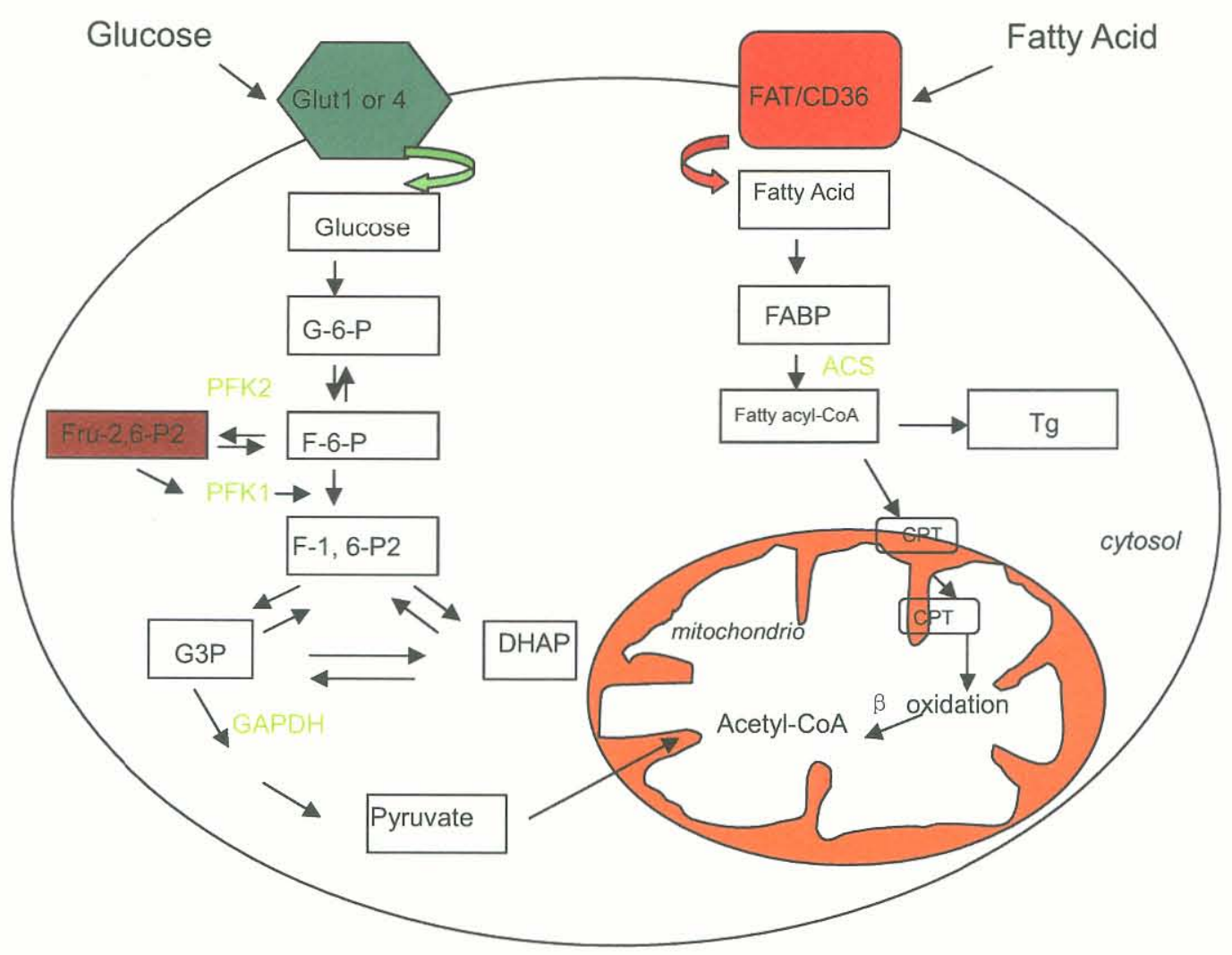

Fig.1. A balance between glucose and fat consumption exists in the healthy cardiomyocyte. Glucose is transported into cytosol by glucose transporters 1 and 4 , and provides $30 \%$ of the energy for the heart through glycolysis and glucose oxidation as shown in the left pathway. Fatty acid is transported into cytosol by transporters FAT/CD36 etc. for fatty acid oxidation, and provides $70 \%$ the energy for the heart as shown in the right pathway. 


\section{FIGURE 2}

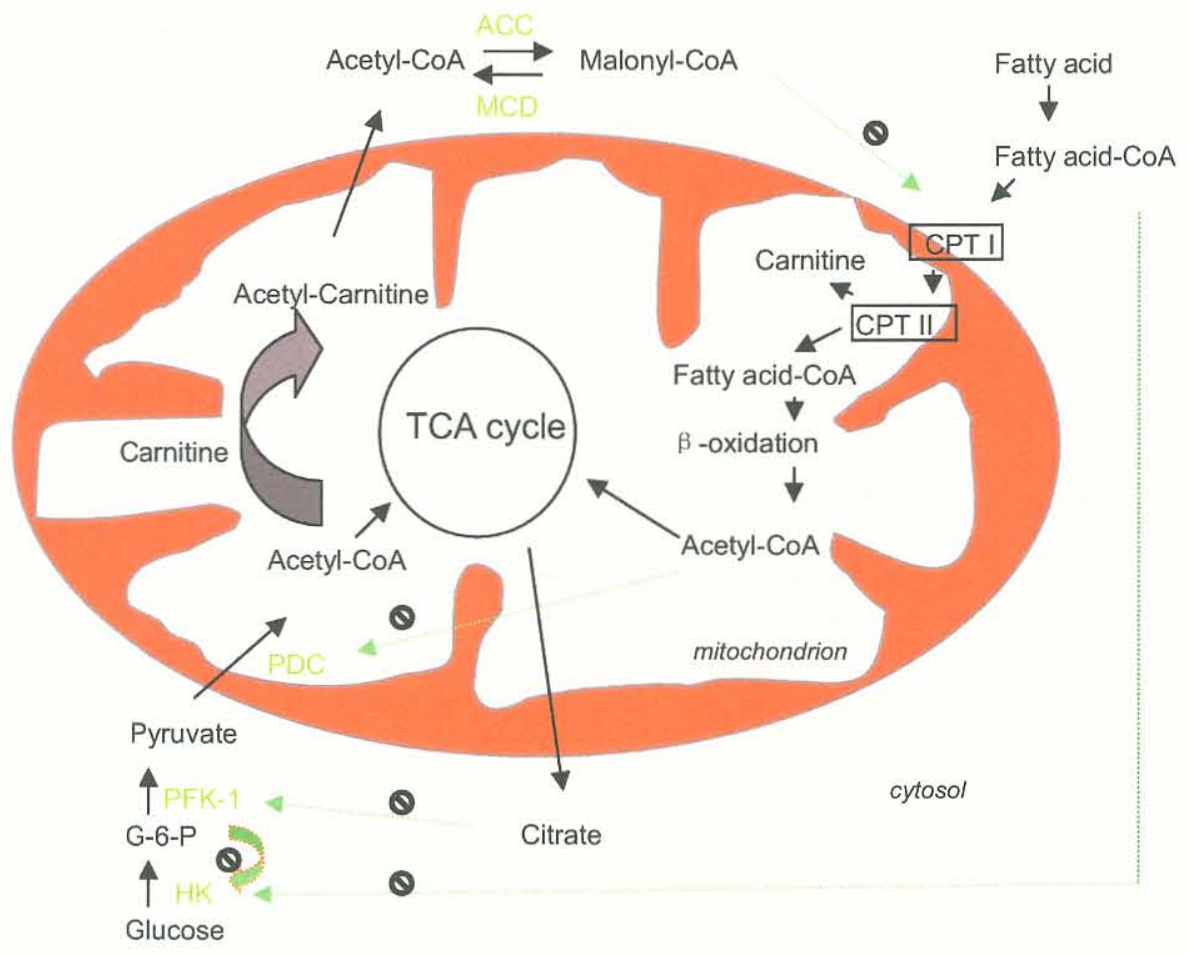

Fig.2. Randle cycle. Glucose metabolites interact with fatty acid metabolites within mitochondria and cytosol. Fatty acid-CoA in cytosol is transported into the mitochondrion by transporters CPT I and CPT II. Acetyl-CoA can be produced from fatty acid in mitochondria via $\beta$-oxidation. The acety-CoA derived from fatty acid oxidation inhibits the activity of pyruvate dehydrogenase complex (PDC) to reduce glucose oxidation, and also enters the TCA cycle for the synthesis of citrate. The citrate can diffuse out of the mitochondrion to the cytosol, inhibiting the activity of PFK-1 which will result in the accumulation of G6P. The accumulated G6P will inhibit the activity of 
hexokinase $(\mathrm{HK})$, and meanwhile the accumulated fatty acid-CoA in the cytosol can also inhibit the activity of $\mathrm{HK}$, with overall reduction of glycolysis and glucose oxidation. Acetyl-CoA derived from glucose can form acetyl-carnitine which is transported out of the mitochondrion to release the glucose-derived acetyl-CoA, favoring synthesis of malonyl-CoA in the cytosol. The increase of malony-CoA will directly inhibit the activity of the transporter CPT I, leading to reduction of the fatty acid oxidation.

Q Indicates inhibition. 
FIGURE 3

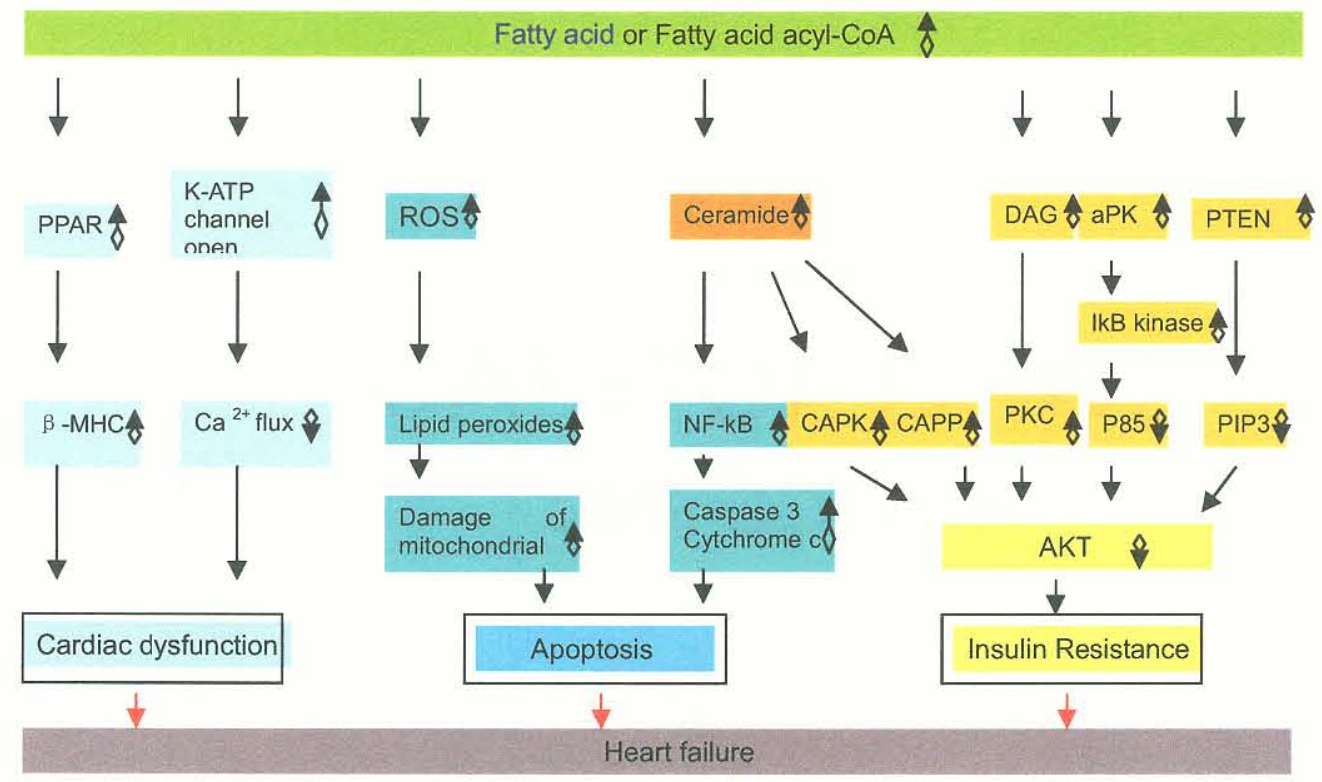

Fig.3. The signal pathways induced by the intracellular accumulation of fatty acids are involved in the development of heart failure. The pathways can be divided into three parts: cardiac dysfunction, apoptosis and insulin resistance. Fatty acid acyl-CoA accumulation in the cytosol can increase the expression of PPAR a, resulting in an increase of the expression of slow contractile protein $\beta$-myosin heavy chain, and can activation of K-ATP channel opening, leading to a decrease of $\mathrm{ca}^{2+}$ flux. Both the increase of $\beta-\mathrm{MHC}$ and decrease of $\mathrm{ca}^{2+}$ flux will decrease cardiac contractility and cardiac dysfunction follows. Fatty acid acyl-CoA accumulation in the cytosol can raise intracellular oxidative stress (ROS) damaging the mitochondria and stimulating the synthesis of ceramide, with a resulting increase in caspase 3 
activity and cytochrome $\mathrm{C}$ release which result in an increase in apoptosis. Insulin resistance also can be induced by the accumulation of fatty acid acyl-CoA through decreasing phosphor-AKT signaling. $\delta$ indicates upregulation, $\vartheta$ indicates downregulation. 


\section{METHODS AND MATERIALS}

\section{Development of transgenic mice}

The

bifunctional

enzyme

6-phosphofructo-2-kinase/fructose-2,6-bisphosphatase (PFK2) controls levels of F-2,6- $\mathrm{P}_{2}$ by catalyzing two opposing reactions: F-6-P + ATP $\rightarrow$ $\mathrm{F}-2,6-\mathrm{P}_{2}+\mathrm{ADP}$ and $\mathrm{F}-2,6-\mathrm{P}_{2} \rightarrow \mathrm{F}-6-\mathrm{P}+\mathrm{P} .1 .6 \mathrm{~kb} \mathrm{Kpnl} /$ Hindlll fragments of the kinase mutant PFK2 cDNA or the bisphosphatase mutant PFK2 cDNA was produced by polymerase chain reaction. An insertion DNA fragment for cardiac specific expression was obtained by cutting a ligated plasmid in which the deficient PFK2 cDNA was inserted behind the a-myosin heavy chain promoter. The insertion DNA fragments for kinase active/bisphosphatase mutant PFK2 or kinase mutant/bisphosphatase active were injected into fertilized embryos to produce transgenic animals. The transgenes were designated Mk (for the MHC promoter and the kinase active with bisphosphatase deficient PFK2 gene) and Mb (for the MHC promoter and the bisphosphatase active with kinase deficient PFK2 gene). Transgenic mice were produced on the FVB background and maintained as heterozygotes by breeding to FVB mice. All procedures conformed to the Guide for the Care and Use of Laboratory Animals published by the US National Institutes of Health (NIH Publication No. 85-23, revised 1996) and 
were approved by the USDA certified institutional animal care committee. Male mice aged $90-130$ days were used in the following studies.

\section{Analysis of F-2,6-P2 content in transgenic mice}

The concentration of $F-2,6-P_{2}$ was measured in the three groups of mice: FVB control, Mb and Mk. First, $0.1 \mathrm{~g}$ of heart tissue was homogenized in 10 volumes $(1 \mathrm{~mL})$ of $50 \mathrm{mM}$ sodium hydroxide, then the tissue was solubilized by heating at $80^{\circ} \mathrm{C}$ for five minutes. The solution was cooled on ice, neutralized with $100 \mu \mathrm{L}$ of $1 \mathrm{M}$ ice cold acetic acid in $20 \mathrm{mM}$ Hepes and the supernatant containing $F-2,6-P_{2}$ was collected by centrifugation at $8000 \mathrm{~g}$ for 10 minutes. $0.25 \mathrm{~mL}$ of the reaction mixture (100 mM TES, pH 8.0, $6 \mathrm{mM}$ $\mathrm{MgCl}_{2}, 1 \mathrm{mM}$ EDTA , $0.1 \mathrm{mM}$ DTT and $0.22 \mathrm{mM} \mathrm{NADH}$ ) was mixed with 20 $\mathrm{uL}$ of the supernatant, then $25 \mathrm{uL}$ of $50 \mathrm{mM} \mathrm{NaPPi}$ (Sodium pyrophosphate) was added. The changes in absorbance for $10 \mathrm{~min}$ at $340 \mathrm{~nm}$ were recorded along with $\mathrm{F}-2,6-\mathrm{P}_{2}$ standards.

\section{Cardiac perfusion}

Mice were anesthetized with ketamine (50 mg/kg, i.p.) and xylazine (2.5 $\mathrm{mg} / \mathrm{kg}$, i.p.) and given heparin (10 $\mathrm{U} / \mathrm{g}$, i.p.). The hearts were retrogradely perfused at $2 \mathrm{ml} / \mathrm{min}$ with Krebs-Henseleit buffer $(\mathrm{KH})$ consisting of $120 \mathrm{mM} \mathrm{NaCl}, 20 \mathrm{mM} \mathrm{NaHCO}_{3}, 4.6 \mathrm{mM} \mathrm{KCl}, 1.2 \mathrm{mM} \mathrm{KH}_{2} \mathrm{PO}_{4}, 1.2 \mathrm{mM}$ $\mathrm{MgCl}_{2}, 1.25 \mathrm{mM} \mathrm{CaCl}_{2} 5 \mathrm{mM}$ glucose and $0.25 \mu \mathrm{Ci} / \mathrm{ml}$ of $\left[5-{ }^{3} \mathrm{H}\right]$ glucose. Throughout the perfusion $\mathrm{KH}$ buffer was continuously equilibrated with $95 \%$ $\mathrm{O}_{2} / 5 \% \mathrm{CO}_{2}$ which maintained a $\mathrm{pH}$ of 7.4 and temperature was maintained at $37^{\circ} \mathrm{C}$. The hearts were paced throughout the procedure at $6 \mathrm{~Hz}(6 \mathrm{~V}, 3 \mathrm{~ms})$. For studying the effect of insulin, baseline glycolysis was determined for the 
first $30 \mathrm{~min}$ followed by $50 \mathrm{~min}$ in the presence of $200 \mu \mathrm{U} / \mathrm{ml}$ insulin. Glycolysis in the presence of palmitate was measured by bringing the perfusate to $0.4 \mathrm{mM}$ palmitate by addition of $1 / 20$ th volume of $8 \mathrm{mM}$ palmitate bound to $10 \% \mathrm{BSA}$ in $\mathrm{KH}$ buffer. Perfusion pressure was monitored on a Gould/Statham p23Db physiological pressure transducer. Contractile force was measured with a Grass FT03 force transducer hooked to the apex of the heart. Transducers were connected to a ETH 400 bridge amplifier which fed into a Powerlab/400 amplifier. Data were analyzed using AD Instruments Chart for Windows version 3.3.5.

\section{Measurement of glycolysis and lactate production}

Tritiated water produced from $\left[5-{ }^{3} \mathrm{H}\right]$ glucose during the perfusion was determined by diffusion. A 400- $\mu$ s sample of cardiac effluent and $25 \mu$ of $0.6 \mathrm{~N} \mathrm{HCl}$ were added to $1.5-\mathrm{ml}$ tubes that were placed inside $20-\mathrm{ml}$ scintillation vials containing $2 \mathrm{ml}$ water. Vials were incubated for $72 \mathrm{~h}$ at $37^{\circ} \mathrm{C}$. The inside tube was removed and Ecolite scintillation fluid was added for counting. Effluent from each time point was assayed in triplicate. For each experiment, background counts were determined by performing the same equilibration with perfusion media that had not passed through the heart. Diffusion efficiency was also measured in each experiment using tritiated water. Lactate concentration was measured in a 6-fold diluted effluent using Sigma kit 826-B.

\section{Isolation of adult mouse ventricular myocytes ${ }^{97}$.}

$\mathrm{Mb}, \mathrm{Mk}$ and FVB control mice were anesthetized with ketamine (50 
$\mathrm{mg} / \mathrm{kg}$, i.p.) and xylazine (2.5 mg/kg, i.p.) and given heparin (10 U/g, i.p.). Their hearts were rapidly removed and perfused at constant pressure $\left(100 \mathrm{cmH}_{2} \mathrm{O}\right)$ at $37^{\circ} \mathrm{C}$ for $\sim 3$ min with a $\mathrm{Ca}^{2+}$-free bicarbonate-based buffer containing (in mM) $120 \mathrm{NaCl}, 5.4 \mathrm{KCl}, 1.2 \mathrm{MgSO}_{4}, 1.2 \mathrm{NaH}_{2} \mathrm{PO}_{4}, 5.6$ glucose, $20 \mathrm{NaHCO}_{3}, 10$ 2,3-butanedione monoxime (BDM; Sigma), and 5 taurine (Sigma), with oxygenation $\left(5 \% \mathrm{CO}_{2} / 95 \% \mathrm{O}_{2}\right)$. Then the perfusate buffer was changed to digestion buffer containing $\mathrm{Ca}^{2+}$-free bicarbonate buffer plus collagenase $(0.5 \mathrm{mg} / \mathrm{ml})$ and $\mathrm{CaCl}_{2} 0.05 \mathrm{mM}$ for $7-10 \mathrm{~min}$ until the hearts became swollen and flaccid. The hearts were removed from cannulation and the left ventricles were separated with blunt forceps in $2 \mathrm{ml}$ digestion buffer. The minced tissues were gently agitated by repeated pipette aspiration, filtered through a $140 \mu \mathrm{m}$ nylon mesh and transferred into conical tubes containing $10 \mathrm{ml}$ of suspension buffer I containing $\mathrm{Ca}^{2+}$-free bicarbonate buffer plus $\mathrm{CaCl}_{2} 0.125 \mathrm{mM}$ and $\mathrm{BSA} 5 \mathrm{mg} / \mathrm{ml}$. After the myocytes were pelleted by centrifuging at 300 rpm for $\sim 10 \mathrm{~min}$, the supernatant was aspirated and the myocytes were resuspended in suspension buffer II containing $\mathrm{Ca}^{2+}$-free bicarbonate buffer plus $\mathrm{CaCl}_{2} \quad 0.250 \mathrm{mM}$ and $\mathrm{BSA}$ $5 \mathrm{mg} / \mathrm{ml}$. The final cell pellet was suspended in suspension buffer III containing $\mathrm{Ca}^{2+}$-free bicarbonate buffer plus $\mathrm{CaCl}_{2} \quad 0.500 \mathrm{mM}$ and $\mathrm{BSA}$ $5 \mathrm{mg} / \mathrm{ml}$. The fresh isolated cardiomyocytes were collected by centrifuging at $300 \mathrm{rpm}$ for $10 \mathrm{~min}$. To reduce contamination, the perfusion setup was washed with $70 \%$ alcohol and then rinsed three times with sterilized distilled water before cannulation. All the solutions were filtered $(0.2-\mu \mathrm{m}$ filter) and equilibrated with $95 \% \mathrm{O}_{2}-5 \% \mathrm{CO}_{2}$ for at least 20 min before use.

\section{Culture of adult mouse cardiac myocytes ${ }^{97}$.}


Culture dishes were precoated for 8 h with $10 \mu \mathrm{g} / \mathrm{ml}$ mouse laminin $(\mathrm{GIBCO})$ in phosphate-buffered saline (PBS; GIBCO) with $1 \%$ penicillin-streptomycin (PS; GIBCO) at room temperature. Freshly isolated cardiac myocytes were suspended in minimal essential medium (MEM; Sigma M1018) containing $1.2 \mathrm{mM} \mathrm{Ca}^{2+}, 2.5 \%$ preselected fetal bovine serum (FBS; GIBCO), and 1\% PS (pH 7.35-7.45). The myocytes were plated at $1 \times 10^{4}$ cells $/ \mathrm{cm}^{2}$ in MEM containing $2.5 \%$ FBS and $1 \%$ PS. After $1 \mathrm{~h}$ of culture in a $5 \% \mathrm{CO}_{2}$ incubator at $37^{\circ} \mathrm{C}$, the medium was changed to $\mathrm{FBS}$-free MEM and this was changed every $48 \mathrm{~h}$ during culture.

\section{Western Blotting}

After the cardiomyocytes were cultured for 1 day, insulin was added to each dish at a concentration of $0,0.1,1,3,5,10,20,30$ or $90 \mathrm{nM}$ for $40 \mathrm{~min}$. The cultured cardiomyocytes were collected and lysed by lysis buffer containing $2 \%$ SDS, $10 \%$ glycerol, and $62.5 \mathrm{mmol} / \mathrm{L}$ Tris $(\mathrm{pH} 7.0)$ and then sonicated. Cell proteins were collected by centrifuging at $12000 \mathrm{rpm}$ at $4^{\circ} \mathrm{C}$ for 10 minutes. The protein concentration was determined, and the sample was mixed with loading buffer $(40 \mathrm{mmol} / \mathrm{L}$ Tris- $\mathrm{HCl}, \mathrm{pH} 6.8,1 \%$ SDS, 50 $\mathrm{mmol} / \mathrm{L}$ dithiothreitol, $7.5 \%$ glycerol, $0.003 \%$ bromophenol blue) and heated at $95^{\circ} \mathrm{C}$ for 5 minutes and then subjected to electrophoresis on a SDS-PAGE gel at $120 \mathrm{~V}$. After electrophoresis, the proteins were transferred to a nitrocellulose membrane in transfer buffer containing $20 \mathrm{mmol} / \mathrm{L}$ Tris, 152 mrnol/L glycine, and $20 \%$ methanol. The membranes were rinsed briefly in PBS and blocked in blocking buffer ( $5 \%$ milk and $0.5 \% \mathrm{BSA})$ at room temperature for 2 hours. After blocking, the membranes were incubated with 
antibodies against P-IR, P-AKT, P-4EBP, P-GSK-3b and actin, then washed

3 times with TBS-T containing $0.05 \%$ Tween-20 and incubated with secondary horseradish peroxidase-conjugated antibody for 1 hour. Signal detection was facilitated with enhanced chemiluminescence (ECL kit, Amersham). Actin expression was used as a loading control.

\section{Phenylephrine administration by pump implantation}

Two-month old FVB control, Mk and Mb7 mice (three groups) were used. Each group of mice was treated with phenylephrine (PE) or PBS ('vehicle control) for 28 days. Alzet miniosmotic pumps (Alza Corp., Mountain V'iew, CA, USA) containing PE (50 mg/kg/day) or PBS were surgically inserted dorsally and subcutaneously under anesthesia by mixture of ketamine $(50 \mathrm{mg} / \mathrm{kg})$ and xylazine $(2.5 \mathrm{mg} / \mathrm{kg})$ given i.p.

\section{Histological Study}

The mice were anesthetized with a combination of ketamine (50 $\mathrm{mg} / \mathrm{kg}$ ) and xylazine $(2.5 \mathrm{mg} / \mathrm{kg}$, i.p.), the hearts were excised and immersed in formalin buffer over night, and then the hearts were embedded in paraffin. $5 \mu \mathrm{m}$ heart sections were placed on slides, deparaffinized and stained with hematoxylin/eosin for histology and with picric acid for analysis of collagen accumulation. The solution of picric acid (saturated, 1\%) contains $0.1 \%$ Sirius red for staining collagen and $0.1 \%$ Fast Green for staining non-collagen proteins. The sections were examined with Nikon Eclipse E600 by light microscopy and images were acquired with SPOT camera. The quantitative analysis of the interstitial fibrosis were done by Adobe 
Photoshop software.

\section{Statistical Analysis}

Data are described by mean \pm SE for normally distributed variables.

For all statistical analyses, 1-way or 2-way ANOVA model and Tukey's post-hoc test were performed for repeated measures. Single comparisons were performed by Student's $t$-test. The difference are considered significant when $\mathrm{P}<0.05$. 


\section{RESULTS}

The data are divided into three parts: in vivo studies, Langendorff perfused heart studies and in vitro cultured cardiomyocyte studies. Figures 4 , 6 and 11 were provided by Dr. Rajakumar Donthi. Figures 12 and 13 were provided by Qianwen Wang. The author is responsible for figures $8,9,10,14$ 15, 16 and 17. Dr. Rajakumar Donthi and the author collaborated on the research shown in figures 5 and 7 .

\section{In Vivo analysis}

1.1 The content of $\mathrm{F}-2,6-\mathrm{P}_{2}$ in $\mathrm{FVB}, \mathrm{Mk}$ and $\mathrm{Mb}$ mice is shown in figure 4. In Mk mice, the kinase active/bisphosphatase inactive PFK-2 mutant CDNA was transfected into FVB background mice and was overexpressed specifically in hearts via a driver of a -myosin heavy chain ( a $-\mathrm{MHC}$ ) promoter. In $\mathrm{Mb}$ mice, the kinase inactive/bisphosphatase active PFK-2 mutant cDNA was transfected into FVB background mice and was overexpressed specifically in hearts being driven by a $-\mathrm{MHC}$ promoter. FVB mice were used as wild type control. F-2,6- $\mathrm{P}_{2}$ increased 3 fold in Mk mice and decreased to $50 \%$ in Mb mice compared to FVB control mice.

1.2 The measurement of heart to body weight ratio. In Mk and Mb 
mice, the ratio of heart weight to body weight significantly increased $15 \%$ and $5 \%$ respectively compared to that in FVB control mice as shown in figure 5 .

1.3 Histology analysis in FVB, Mb and Mk mice is shown in figure 6 and figure 7. Cardiac fibrosis was significantly increased in both Mk and $M b$ transgenic hearts compared to FVB control mice.

1.4 The effects of treatment with phenylephrine on $\mathrm{Mk}, \mathrm{Mb}$ and FVB control mice is shown in figures 8,9 and 10. Phenylephrine treatment increased cardiac afterload, inducing heart failure. At a dose of $50 \mathrm{mg} / \mathrm{kg} / \mathrm{day}$ of phenylephrine, Mk and $\mathrm{Mb}$ transgenic mice had higher mortality than FVB control mice. The death of cardiomyocytes by HE staining was observed in $\mathrm{Mk}$ and $\mathrm{Mb}$ hearts but not in FVB control hearts. Furthermore, hearts from Mb mice seemed weaker than Mk mice.

\section{Langendorff perfused heart data}

2.1 The effect of $\mathrm{Mb}$ transgene on cardiac glycolysis was assessed in Langendorff-perfused hearts by measuring the consumption of 5-tritiated glucose and the production of lactate. ${ }^{3} \mathrm{H}_{2} \mathrm{O}$ is released from the metabolism

of $\left[5-{ }^{3} \mathrm{H}\right]$ glucose by the triose-phosphate isomerase and the enolase steps of the glycolytic pathway. As shown in figure 11 , both ${ }^{3} \mathrm{H}_{2} \mathrm{O}$ and lactate release were significantly reduced in $\mathrm{Mb}$ transgenic hearts. Perfusion pressure was constant at $65 \mathrm{~mm} \mathrm{Hg}$ and flow rate was stable and equal in $\mathrm{Mb}$ and $\mathrm{FVB}$ 
FIGURE 4

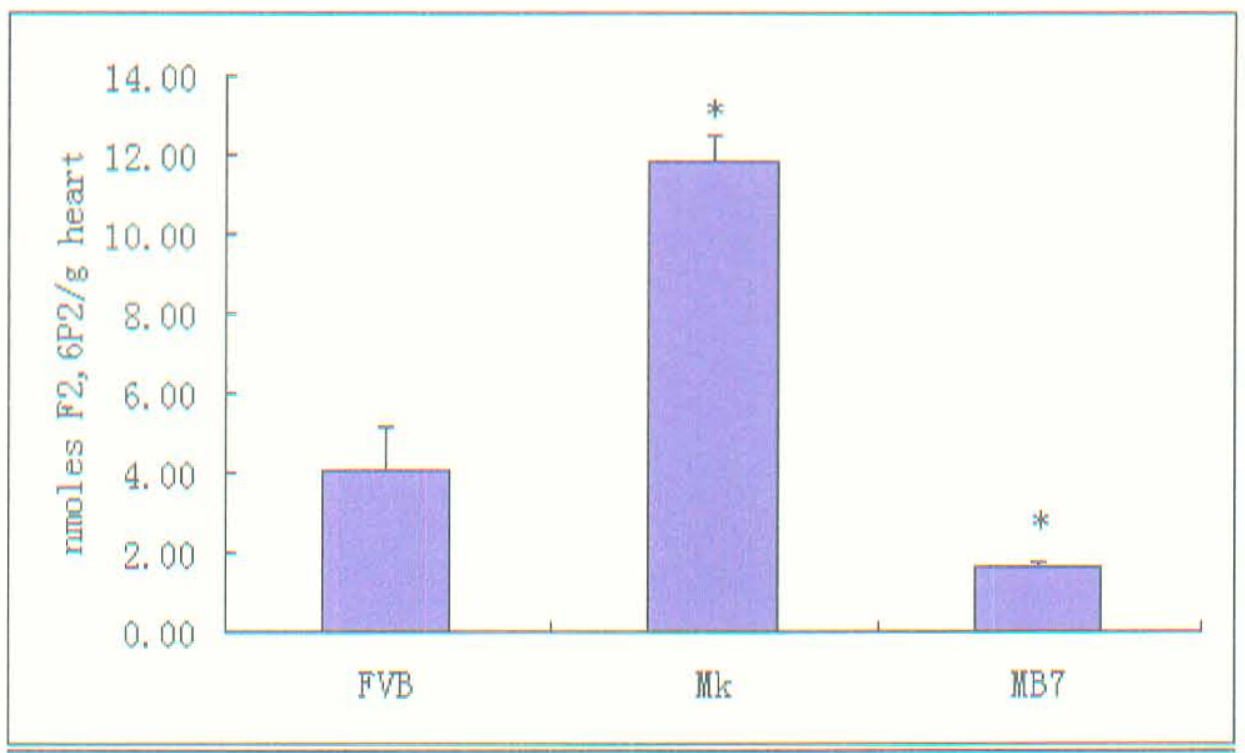

Fig.4. $\mathrm{F}-2,6-\mathrm{P}_{2}$ content in $\mathrm{Mk}, \mathrm{Mb}$ and $\mathrm{FVB}$ control mice. F-2,6- $\mathrm{P}_{2}$ increased significantly, almost three fold higher in Mk than in FVB control while F-2,6- $\mathrm{P}_{2}$ content in $\mathrm{Mb}$ mice decreased significantly to $50 \%$ of FVB control. The values shown are mean \pm SE and were analyzed by one way ANOVA (*: $p<0.05, n=4$ leach group) 
FIGURE 5

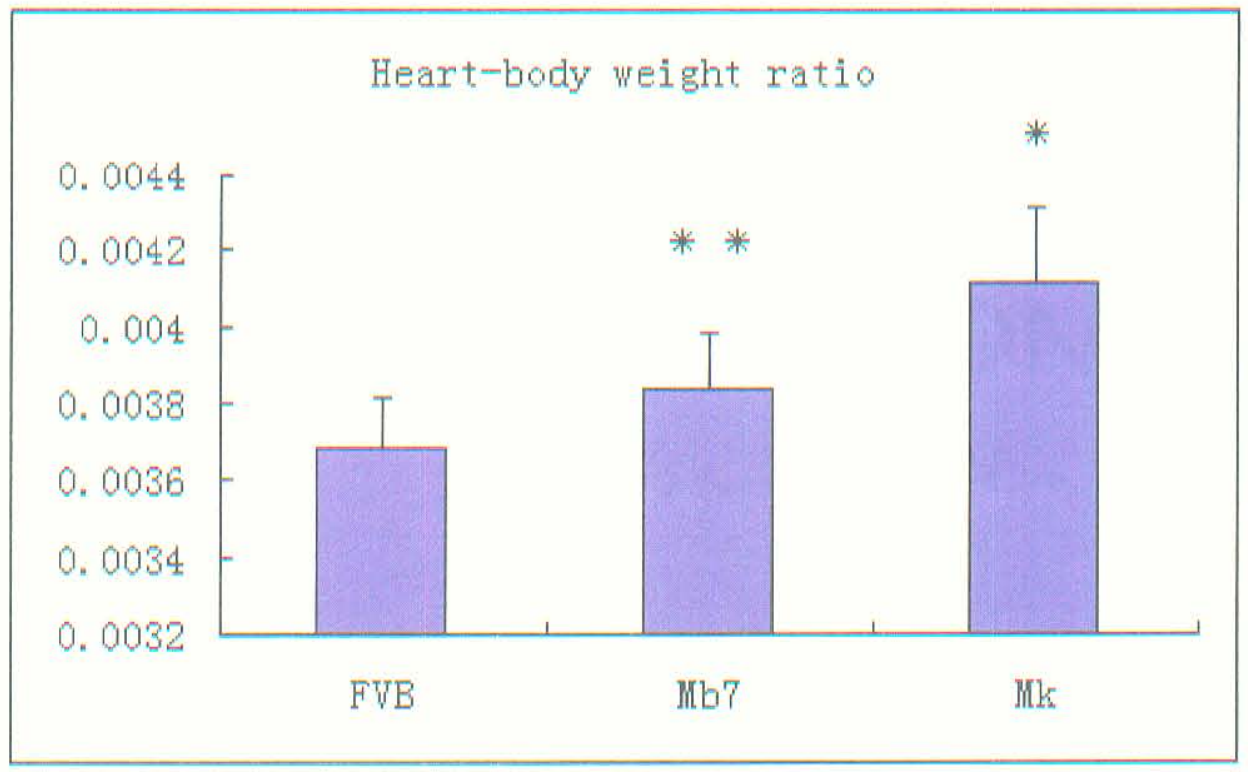

Fig .5.The figure shows the heart to body weight ratio in FVB, Mb and Mk mice. The ratio of heart to body weight significantly increased $5 \%$ in $\mathrm{Mb}$ mice and $15 \%$ in Mk mice compared to FVB control. Therefore Mb and Mk hearts showed mild hypertrophy. The data were analyzed by one way ANOVA analysis. ${ }^{*}: p<0.01,{ }^{* *}: p<0.05$ compared to FVB. 


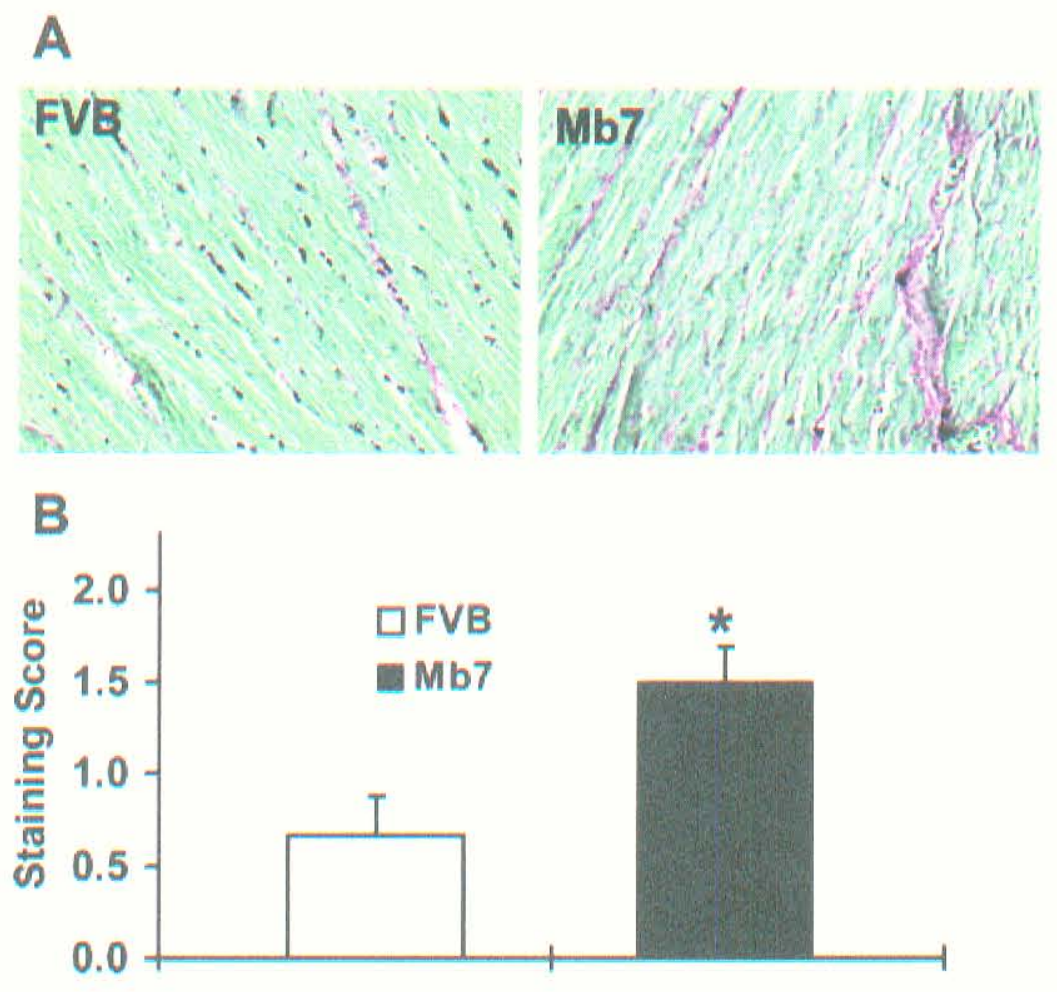

Fig.6. Collagen accumulation in FVB and Mb hearts. Sirius red staining was visualized at $\times 40$ and photographed. $A$, representative collagen staining for FVB and $\mathrm{Mb}$ mice. $B$, scoring of collagen content in 14 photographs taken from FVB (3) and Mb (4) mouse hearts. Staining was rated by a blind observer on a scale of $0-2$, where 0 indicates mild, 1 increased, and 2 severe interstitial accumulation of collagen. The values shown are mean \pm S.E. and were analyzed by ANOVA on Rank test $(, p<0.01)$. 


\section{FIGURE 7}

A

FVB

MK

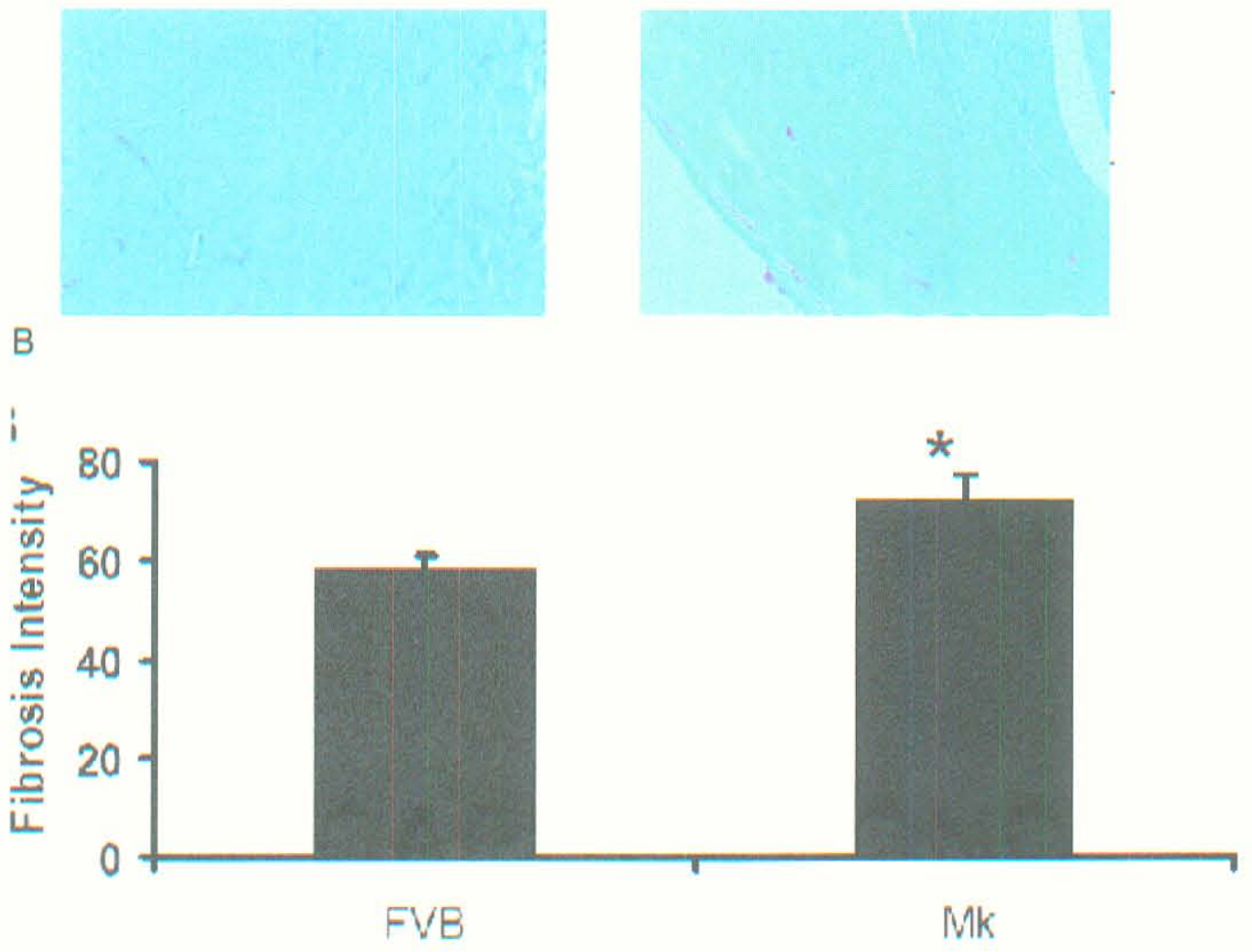

Fig. 7. Histology of FVB and Mk hearts. Collagen accumulation was visualized by Sirius red staining at $\times 40 . A$, representative Sirius red staining of FVB and $M k$ hearts. $B$, scoring of collagen content in 30 photographs taken from FVB (3) and Mk (3) mouse hearts. Staining intensity was rated by Adobe Photoshop software. The values shown are mean \pm S.E. and were analyzed by Student's test $(: p<$ $0.001)$. 
FIGURE 8

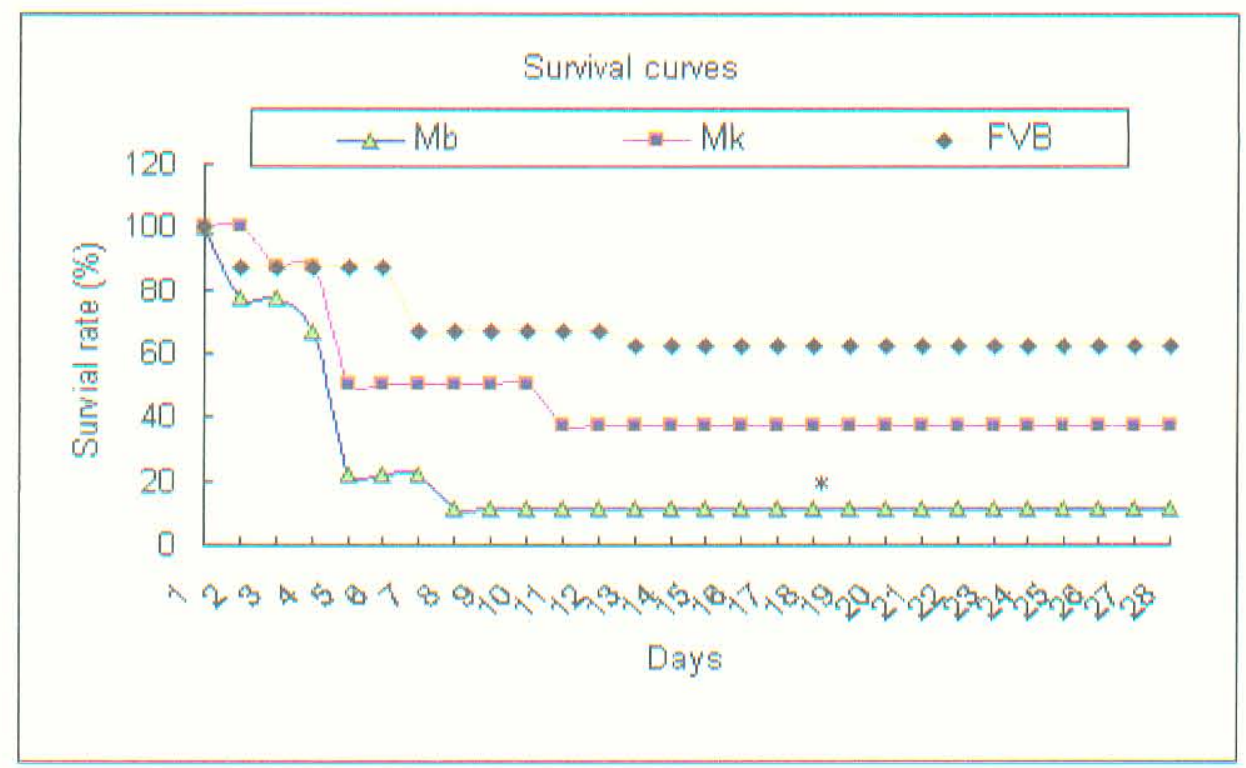

Fig.8. Survival curves of $\mathrm{Mb}, \mathrm{Mk}$ and FVB mice following treatment of phenylephrine for 28 days (implantation of pumps at dose of $50 \mathrm{mg} / \mathrm{kg} / \mathrm{day}$ ). Higher mortalities in transgenic mice $\mathrm{Mb}$ and $\mathrm{Mk}$ were found; moreover, the mortality of Mb mice was higher than of Mk mice. Unfortunately, No significant differences were found within the comparisons of Mk vs. Mb, Mk vs. FVB and FVB vs. Mb through Kaplan-Meier survival analysis $(M b$ vs. $F V B *, p=0.067, n=8 /$ each group ). It is possible that if more mice are tested, a significant difference may be observed. 


\section{FIGURE 9}

FVB

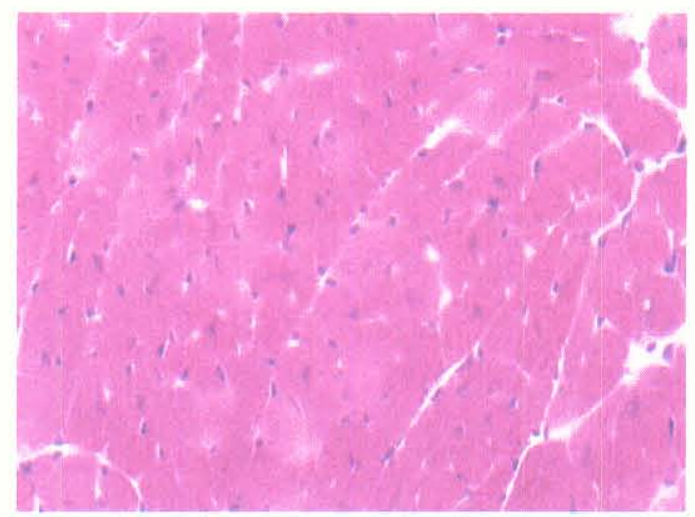

Mk

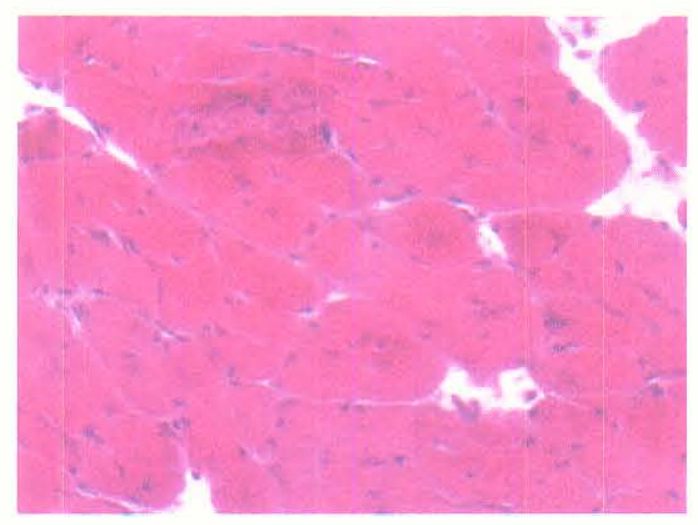

$\mathrm{Mb}$

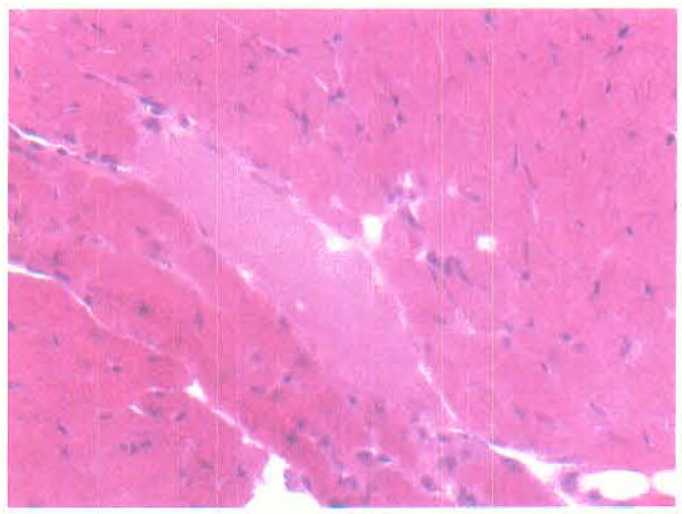

Fig.9. HE staining on FVB control, Mb and Mk hearts after being treated with phenylephrine for 3 days. The HE staining was visualized at $\times 40$ and photographed. The death of cardiomyoctyes was found in Mb and Mk not in FVB control mice. The hearts from $\mathrm{Mk}$ and $\mathrm{Mb}$ mice seemed more susceptible to phenylephrine treatment than that from FVB control mice. 


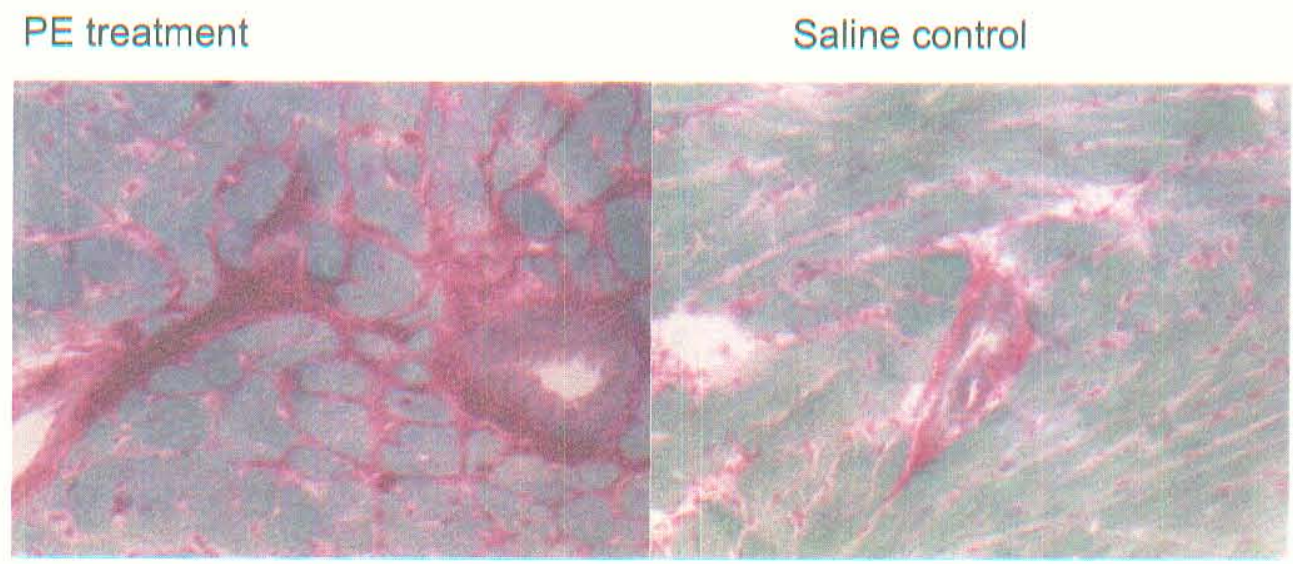

Fig.10. Histology of FVB hearts with phenylephrine and saline treatment respectively. Sirius red staining was visualized at $x 40$ and photographed. Fibrosis accumulated in the heart from FVB mice with PE treatment for 28 days compared to that from FVB control mice with saline treatment 
hearts throughout the experiment. After addition of insulin to the perfusate, the difference in metabolism between transgenic and control hearts became even greater because of a clearly diminished response to insulin in transgenic hearts (Fig. 11C and D). At the end of the 50-rnin perfusion with insulin, 5-tritiated glucose consumption was increased by $70 \%$ in FVB hearts but only by $34 \%$ in transgenic hearts (Fig. 11C). Similarly, lactate output was increased by $90 \%$ in FVB hearts but only by $25 \%$ in Mb hearts (Fig. 11D). The differences in the response to insulin were significant $(p<0.02)$.

\subsection{Effect of Kinase Active PFK-2 on Cardiac Glucose Metabolism}

The effect of Mk transgene on glycolysis was assessed in Langendroff-perfused hearts by measuring metabolism of 5-tritiated glucose and lactate production. Glycolysis was measured by the release of tritiated water through the triose phosphate isomerase reaction. As shown in Figure 12, in the presence or absence of palmitate, the release of ${ }^{3} \mathrm{H}_{2} \mathrm{O}$ and lactate was significantly elevated in Mk transgenic hearts compared to control hearts. The Mk effect was evident both before and after addition of insulin. The increase in glycolysis did not appear to be related to contractility or perfusion pressure: no significant difference was observed for contractility between transgenic and control hearts at any time point (data not shown). Also in both groups, perfusion pressure averaged $65 \mathrm{~mm} \mathrm{Hg}$ while the flow rate was maintained at $2 \mathrm{ml} / \mathrm{min}$. 
A

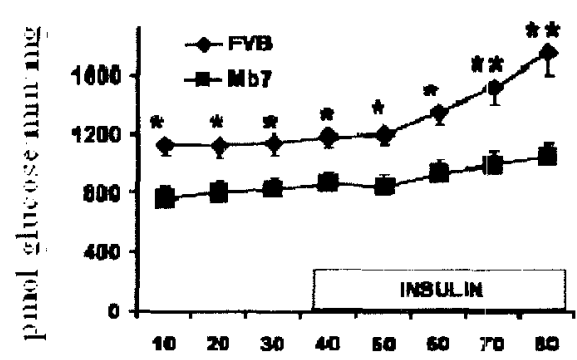

C

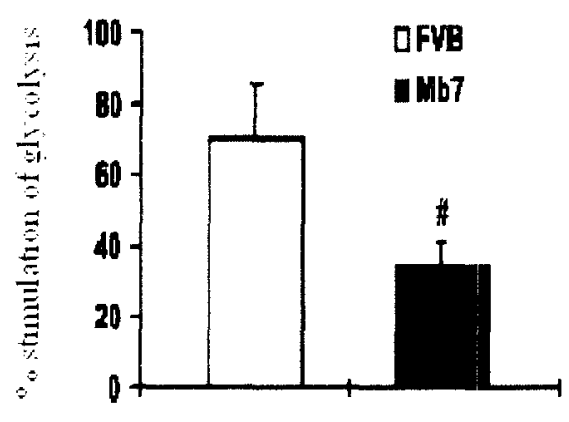

B

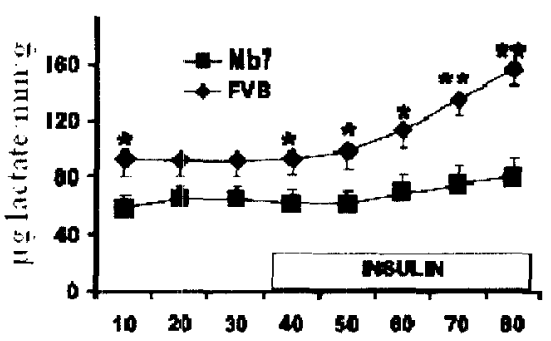

D

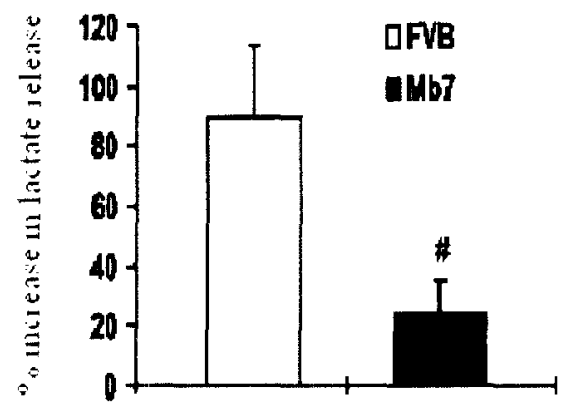

Fig.11. Cardiac glycolysis and stimulatory effect of insulin were reduced in $\mathrm{Mb}$ mice. Glycolysis was measured by consumption of $\left[5-{ }^{3} \mathrm{H}\right]$ glucose $(A)$ and lactate release $(B)$. The lower graphs show the percent increase in glycolysis $(C)$ and lactate release $(D)$ produced by the $50 \mathrm{~min}$ stimulation with insulin. Values shown are mean \pm S.E. for FVB (12) and Mb (14) mice. Panels $A$ and $B$ were analyzed by two-way repeated measures ANOVA followed by Tukey post-hoc test. Panels $C$ and $D$ were analyzed by Student's $t$ test. ", $p<0.05$; $", p<0.002 ; \#, p<0.02$ 
To determine if the transgene altered the effect of palmitate, the results for tritiated water release were replotted in Figure 13. As shown in Figure 13A palmitate significantly reduced glycolysis in FVB hearts but had no clear effect on glycolysis in Mk transgenic hearts (Figure 13B).

\section{In Vitro data on insulin signaling}

Cardiomyocytes were challenged by insulin at different concentrations $(0,0.1,1.0,3.0,5.0,10.0,20.0,30.0$ and $90.0 \mathrm{nM})$. Total proteins from the cultured cardiomyocytes were isolated by lysis buffer and used for Western blot analysis. The insulin signals including Phospho-AKT (p-AKT), Phospho-insulin receptor (P-IR), Phospho-4EBP1 and Phospho-GSK-3b were investigated.

3.1 P-AKT and P-IR signals in FVB, Mb and Mk mice (see figure 14) P-AKT signals in cultured cardiomyocytes were significantly higher in $\mathrm{Mk}$ and $\mathrm{Mb}$ transgenic mice when challenged by different concentrations of insulin compared to FVB control mice. The maximum increase of P-AKT signal in Mk and $\mathrm{Mb}$ mice reached $20 \%$ at $20 \mathrm{nM}$ insulin. P-AKT signal of Mk mice was similar to that of $\mathrm{Mb}$ mice. $\mathrm{EC}_{50}$ for P-AKT in Mk mice was $2.4 \mathrm{nM}$ and maximum response in $\mathrm{Mk}$ mice was 0.24 . $\mathrm{EC}_{50}$ and maximum response for P-AKT in $\mathrm{Mb}$ mice were $2.3 \mathrm{nM}$ and 0.252 respectively, and $\mathrm{EC}_{50}$ and maximum response for P-AKT in FVB control mice were $2.5 \mathrm{nM}$ and 0.188 respectively. The response of P-IR to insulin stimulation among the three group mice was similar.

3.2 Replot of P-IR curve vs. P-AKT curve in FVB, Mb and Mk mice (see figure 15)

P-AKT signals reached peak level at 20nM of insulin stimulation in 
all three group mice. Surprisingly the increase in P-AKT was evident at $1 \mathrm{nM}$ while the P-IR response did not begin until 5nM insulin.

3.3 P-4EBP1 signal in FVB, Mb and MK mice in figure 16

P-4EBP1 is a downstream product of P-AKT. According to previous results, insulin concentration of 10 and $20 \mathrm{nM}$ was chosen. P-4EBP1 signal was significantly increased in all three groups of mice with insulin treatment compared to non-insulin stimulated mice. No significant differences were found among the three groups of mice with insulin treatment.

3.4 P-GSK-3b signal in FVB, Mb and MK mice as shown in figure 17.

P-GSK-3b is another downstream product of P-AKT. The insulin concentration of 10 and $20 \mathrm{nM}$ was also chosen. P-GSK-3b signal was significantly increased in all three groups of mice with insulin treatment compared to non-insulin stimulated mice. No significant differences were found among the three groups of mice with insulin treatment. 


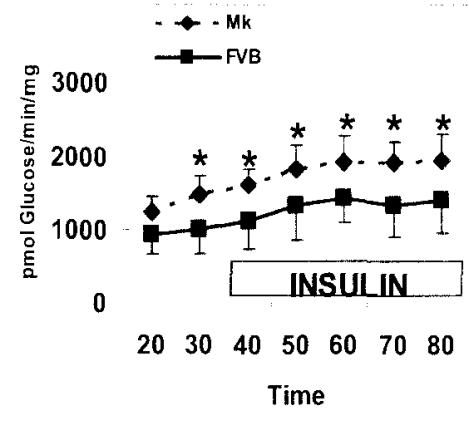

A

B
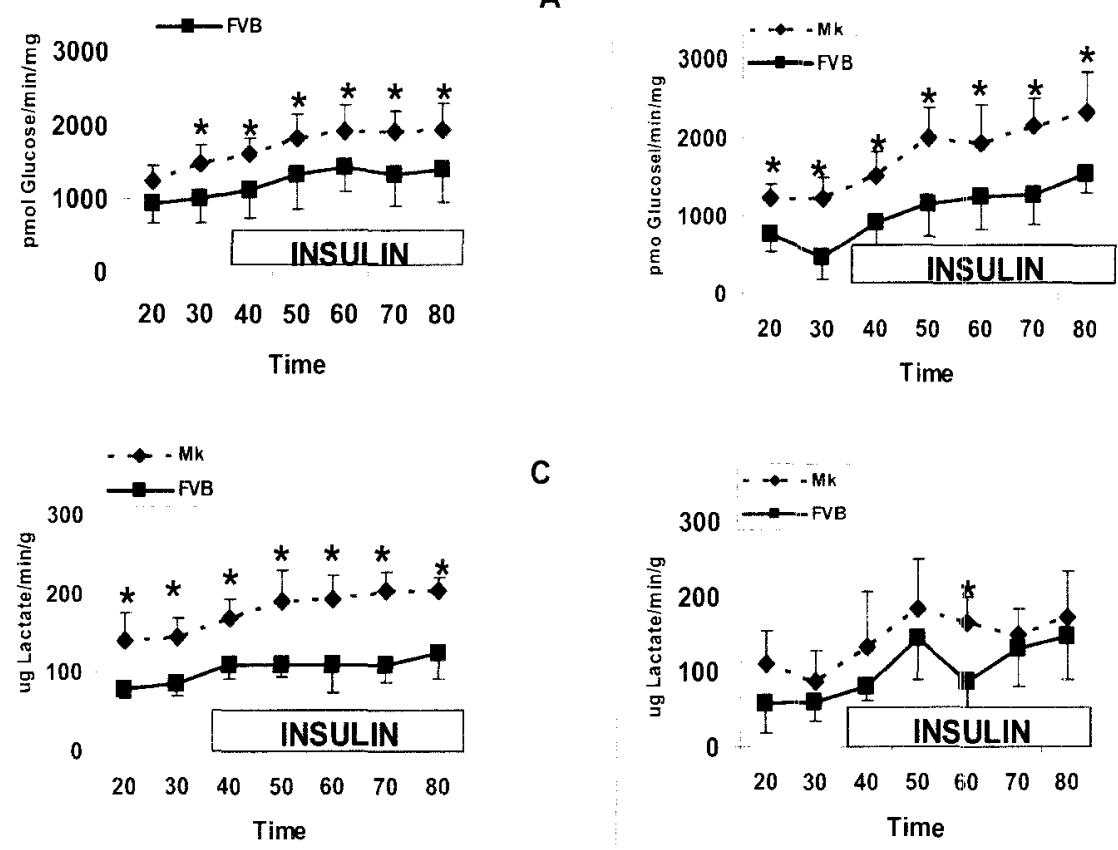

C

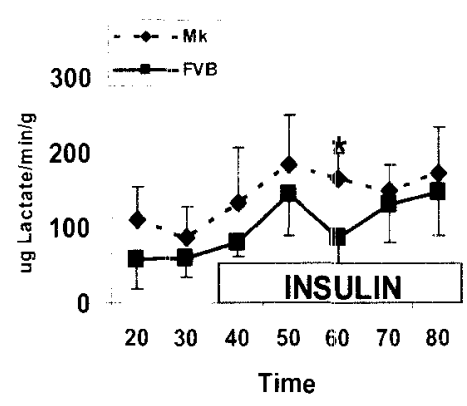

D

Fig.12. Effect of kinase active PFK-2 on glycolysis with or without $0.4 \mathrm{mM}$ palmitate before and after addition of $200 \mu \mathrm{U} / \mathrm{ml}$ insulin. Hearts were isolated and glycolysis was measured using $5-{ }^{3} \mathrm{H}$-glucose (A) Glycolysis without palmitate. (B) Glycolysis with palmitate (C) Lactate release without palmitate (D) Lactate release with palmitate. The values for FVB and Mk were compared by two way ANOVA ( $\left.{ }^{*}: p<0.05\right)$. Values shown are means \pm SE for at least 5 mice per point. 
FIGURE 13

A

B
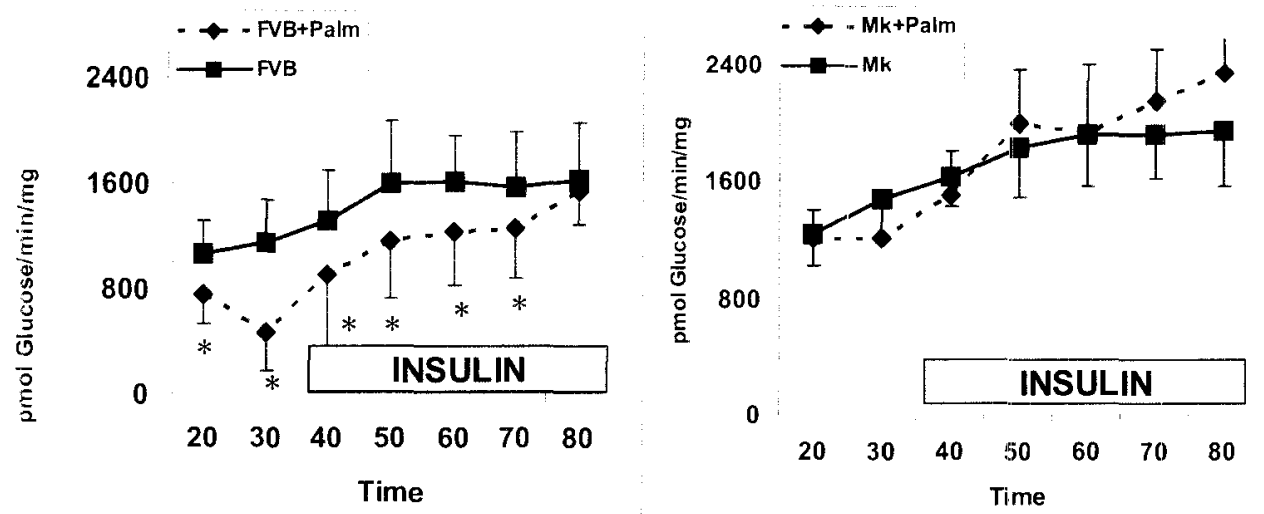

Fig.13. The effect of palmitate on glycolysis in FVB mice (A) and Mk mice (B).

Two way ANOVA indicated that palmitate significantly reduced glycolysis in FVB mice $(p<0.05)$ but had no effect in Mk mice. Data are replotted from Figure 12. 


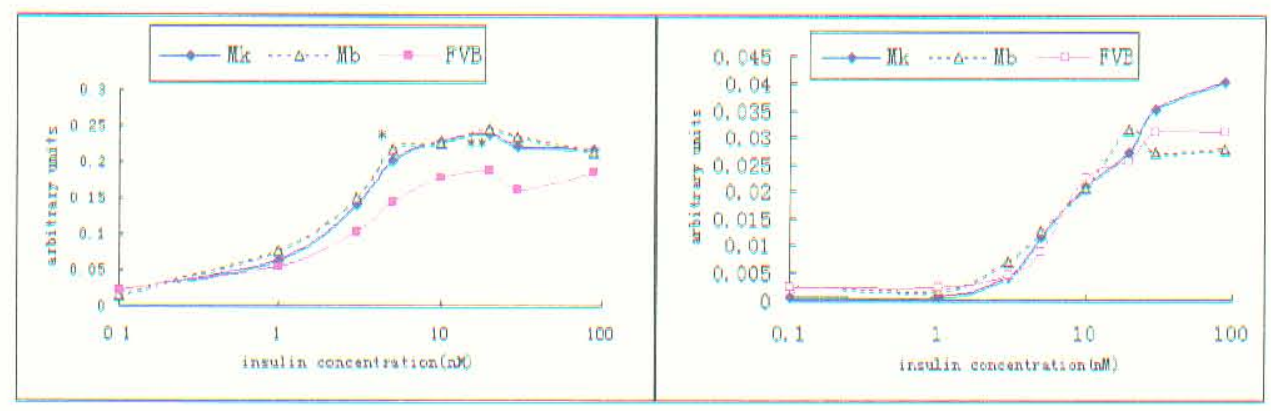

Fig.14. Log concentration-response curves for P-AKT and P-IR signals in cultured cardiomyocytes when stimulated by different concentrations of insulin. The signals of P-AKT in A were found significantly higher in Mk and $\mathrm{Mb}$ mice compared to FVB mice. The maximum increase of P-AKT signals in Mk and $\mathrm{Mb}$ mice reached $20 \%$. EC 50 of P-AKT in Mk mice was $2.4 \mathrm{nM}$ and maximum response in $\mathrm{Mk}$ mice was $0.24 . \mathrm{EC}_{50}$ and maximum response for P-AKT in $\mathrm{Mb}$ mice were $2.3 \mathrm{nM}$ and 0.252 respectively, and $\mathrm{EC}_{50}$ and maximum response for P-AKT in FVB control mice were 2.5nM and 0.188 respectively No significance was found between $\mathrm{Mk}$ and $\mathrm{Mb}$ mice. In $\mathrm{B}$, it is shown that the response of P-IR to insulin stimulation was similar and no significant differences were found among the three groups. $\left({ }^{*},{ }^{* *}, p<0.05\right.$ by 2-way ANOVA analysis vs. FVB control mice) 
FIGURE 15

A: FVB mice

B: Mb mice

C: Mk mice

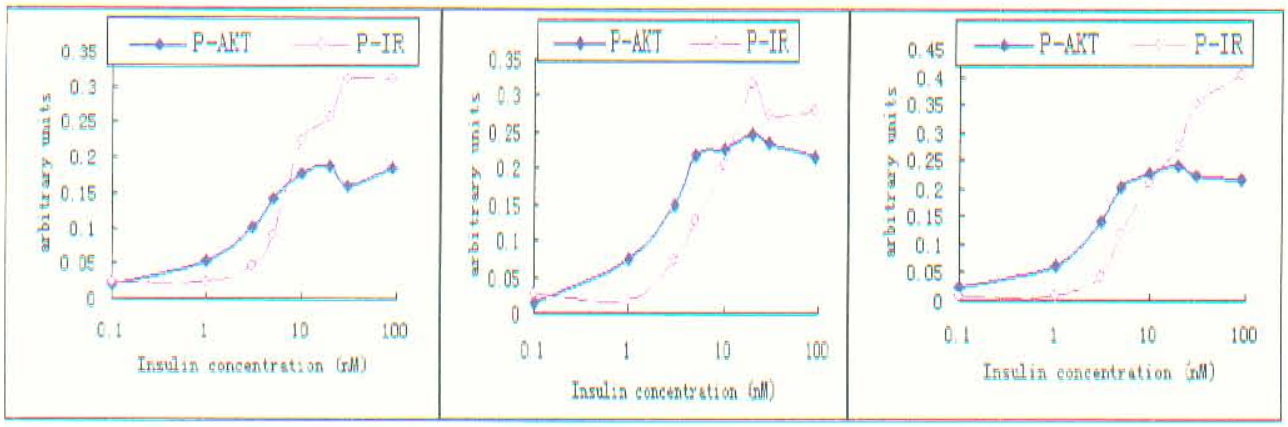

Fig.15. $\mathrm{P}-\mathrm{IR}$ and $\mathrm{P}-\mathrm{AKT}$ in FVB (A), Mb (B) and $\mathrm{Mk}(\mathrm{C})$ mice. P-AKT signals reached peak level at $20 \mathrm{nM}$ of insulin stimulation in all three group mice. Surprisingly the increase in P-AKT was evident at $1 \mathrm{nM}$ while the P-IR response did not begin until 5nM insulin. 


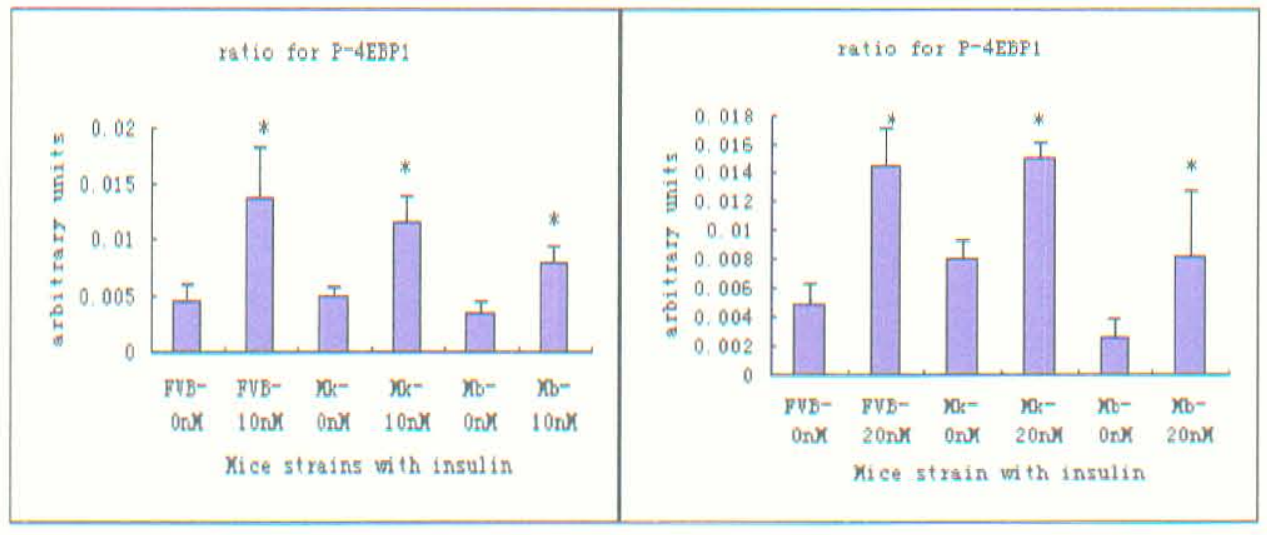

Fig.16. P-4EBP1 in cultured cardiomyocytes challenged by insulin at 0, 10 or 20.0nM. P-4EBP1 signal was significantly increased in all three groups of mice with insulin treatment compared to non-insulin stimulated group. No significant differences were found among the three groups of mice with insulin treatment $\left({ }^{*}, p<0.05\right.$ by one way ANOVA vs. OnM insulin) 


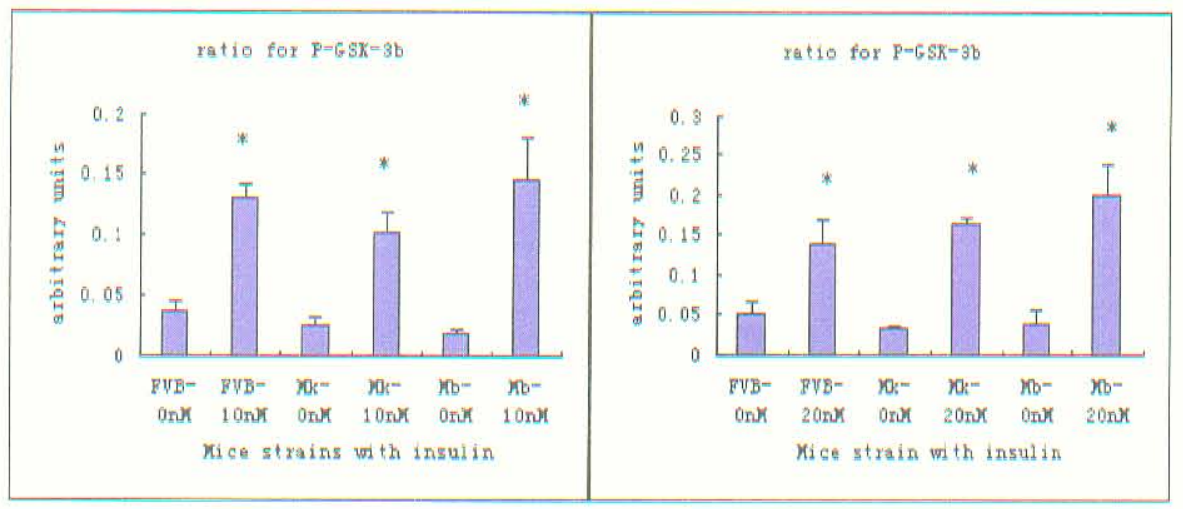

Fig.17. P-GSK-3b in the cultured cardiomyocytes challenged by insulin at 0 , 10 or 20.0nM. P-GSK-3b signal was significantly increased in all the three groups of myocytes with insulin treatment compared to non-insulin stimulated myocytes. No significant differences were found among the three groups of mice with insulin treatment $\left({ }^{*}, p<0.05\right)$ 


\section{DISCUSSION}

Our data show that the $\mathrm{F}-2,6-\mathrm{P}_{2}$ content in Mk hearts was increased 3 fold compared to FVB control, in contrast $\mathrm{F}-2,6-\mathrm{P}_{2}$ in $\mathrm{Mlb}$ hearts decreased to $50 \%$ of control. $\mathrm{F}-2,6-\mathrm{P}_{2}$ is a potent stimulator of the glycolytic regulatory enzyme PFK1. The glycolytic effect of the Mk and Mb transgene was assessed in Langendorff-perfused hearts by the release of tritiated water from 5-tritiated glucose through the triose phosphate isomerase reaction, while lactate was also detected. As shown in figure 12, in the presence or absence of palmitate, the release of ${ }^{3} \mathrm{H}_{2} \mathrm{O}$ and lactate was significantly elevated in Mk transgenic hearts compared to control hearts. Whereas in Mb transgenic hearts shown in figure 11, the release of ${ }^{3} \mathrm{H}_{2} \mathrm{O}$ and lactate decreased significantly in the absence of palmitate. The $\mathrm{Mk}$ and $\mathrm{Mb}$ transgenic effects were evident both before and after the addition of insulin. As shown in Figure 13B palmitate could not significantly reduce glycolysis in Mk transgenic hearts but was effective in FVB hearts (Figure 13A), demonstrating that regulation of $\mathrm{F}-2,6-\mathrm{P}_{2}$ could overcome fat-induced glycolytic inhibition. Both increased glycolysis caused by elevated $F-2,6-P_{2}$ in Mk mice and decreased glycolysis caused by reduced $\mathrm{F}-2,6-\mathrm{P}_{2}$ in $\mathrm{Mb}$ mice produced detrimental actions in heart such as hypertrophy and cardiac fibrosis as shown in figures 5,6 and 7. Treatment with phenylephrine was 
also used to assess heart capabilities from FVB control, Mb and Mk mice. Phenylephrine usually increase cardiac afterload, as data in figure 10 shows that stronger perivascular collagen deposits were found in FVB control mice after being treated with phenylephrine for 28 days. Figure 8 shows higher mortality in $\mathrm{Mb}$ and $\mathrm{Mk}$ transgenic mice, moreover, mortality of $\mathrm{Mb}$ mice was slightly higher than that of Mk mice. When the mice were treated with phenylephrine for 3 days, HE staining data in figure 8 shows cardiomyocyte death in Mb and Mk mice but not in FVB control mice. Therefore, Both Mk and $\mathrm{Mb}$ hearts seemed weaker than those of FVB control mice.

\section{Glucose toxicity and Lipid toxicity in Mb and Mk mice}

As illustrated in Figure 1 and 2, there is a balance between the metabolism of glucose and that of fatty acid, which is called the Randle cycle. Increased glucose utilization may inhibit fatty acid oxidation and result in the accumulation of fatty acid in cytosol, while decreased glucose utilization may enhance the fatty acid utilization and increase cellular oxidative stress. In Mk transgenic mice, accumulation of fatty acid in cardiomyoctyes due to increased glucose utilization could result in lipotoxicity as shown in Figure 3. The lipotoxicity may cause cardiac dysfunction, apoptosis and insulin resistance through multiple signal pathways, eventually resulting in cardiac hypertrophy and heart failure. Increased glycolysis stimulated by F-2,6-P2 also can cause glucotoxicity, for which two pathways can be hypothesized, one is by $\mathrm{PKC}$, another is by $A G E^{55}$. In Mb mice, decreased glycolysis will be expected to increase fatty acid oxidation, and increased consumption of fatty acids may provoke more ROS from mitochondria. Decreased glycolysis also 
can cause glucose toxicity through other pathways, one is to increase polyol pathway influx, another is hexosamine pathway ${ }^{55}$.

In $\mathrm{Mb}$ mice, reduced $\mathrm{F}-2,6-\mathrm{P}_{2}$ will be expected to decrease the activity of PFK-1, the upstream metabolites of glycolysis at the point of PFK-1 may accumulate due to the reduced activity of PFK-1 such as F-6-P and/or G-6-P and glucose in cardiomyocytes. Accumulation of glucose in cardiomyocytes could activate the polyol pathway and the accumulated F-6-P could stimulate the hexosamine pathway. In the polyol pathway, aldose reductase is the first enzyme and catalyses the NADPH-dependent reduction of a wide variety of carbonyl compounds such as glucose to sorbitol, with consumption of NADPH, and further the sorbitol can be oxidized to fructose by the enzyme sorbitol dehydrogenase, with $\mathrm{NAD}^{+}$reduced to $\mathrm{NADH}^{55}$. In this polyol pathway, NADPH is decreased and more glutathione (GSH) needs to be generated, but too much consumption of GSH can increase intracellular oxidative stress. The reduction of glucose utilization in $\mathrm{Mb}$ mice leading to elevation of fatty acid utilization may also raise intracellular oxidative stress. Therefore, oxidative stress (ROS) should be very high in $\mathrm{Mb}$ mice. The increased intracellular oxidative stress could activate multiple signal pathways and could result in cell apoptosis and necrosis, leading to cardiac dysfunction, hypertrophy and heart failure ${ }^{60,86}$. In the hexosamine pathway, the accumulated F-6-P in Mb mice can be diverted from glycolysis and be a substrate for glutamine:fructose-6-phosphate amino transferase (GFAT) for producing glucosamine, and further forming UDP-N-acetyl glucosamine (GlcNAc).The GlcNAc can modify various cytosolic proteins and transcriptional factors by O-GlcNAcylation, either reducing or enhancing 
their activities, which are associated with development of diabetic complications $^{65}$. Because phosphorylation plays an important role in protein activity and transcriptional activity, O-GIcNAcylation and phosphorylation often occur reciprocally in transcription factors, thus O-GIcNAcylation competing with phosphorylation may enhance or inhibit the transcriptional activities, for example, Sp1 has shown some competing sites between phosphorylation and O-GicNAcylation affecting Sp1 transcriptional activities $^{65,96}$; A fourfold increase in O-acetylglucosaminylation of Sp1 result in a reciprocal $30 \%$ decrease in the level of serine-threonine phosphorylation of Sp156; hyperglycemia can induce a 2.4 -fold increase in hexosamine pathway activity in aortic endothelial cells, resulting in a 1.7-fold increase in Sp1 O-linked GIcNAc and a 70-80\% decrease in Sp1 O-linked phosphothreonine and phosphoserine ${ }^{55,61}$, furthermore, hyperglycemia can increase expression of an 85-base-pair truncated PAl-1 promoter-luciferase reporter DNA containing two Sp1 sites by 3.8 fold but fails to act when the two $\mathrm{Sp} 1$ sites are mutated ${ }^{5,51}$. Therefore, activation of the hexosamine pathway by hyperglycemia may result in many changes in both gene expression and protein function, which together contribute to the pathogenesis of diabetic complications ${ }^{65}$. In Mb mice, Sp1 activity may be increased by the hexosamine pathway due to modification of Sp1 by glycosylation. Sp1 activity is associated with gene expression of MMP, TIMP and TGF-beta, PAI-1, which are involved in cardiac remodeling and fibrosis formation $^{88}$.

In Mk transgene mice, increased $\mathrm{F}-2,6-\mathrm{P}_{2}$ will increase the activity of PFK1, producing over amount of product $\mathrm{F}-1,6-\mathrm{P}_{2}$. The over amount of 
$\mathrm{F}-1,6-\mathrm{P}_{2}$ may exceed the capacities of downstream enzymes to metabolize them, meanwhile $\mathrm{F}-1,6-\mathrm{P}_{2}$ can balance reversibly with DHAP and GAP. Therefore increased $\mathrm{F}-2,6-\mathrm{P}_{2}$ probably lead to the accumulation of dihydroxyacetone phosphate (DHAP) and GAP metabolites. Accumulated GAP metabolites can form methylglyoxal, producing advanced glycolyation endproducts (AGE). AGE formed from glucose is much slower than that from glucose-derived dicarbonyl precursors such as glyoxal, 3-deoxyglcosone and methyglyoxal ${ }^{84}$. In Mk mice, due to high activity of PFK-1, intracellular methygloxal product could be higher than that in normal mice. The higher methygloxal content inside cells, the more intracellular AGEs produced. Intracellular AGE precursors can damage target cells by modifying intracellular proteins, by altering intracellular protein function and activities, and by modifying extracelluar matrix components interacting abnormally with other matrix component and with receptors on cells such as intergrins, and by modifying plasma proteins binding to AGE receptors, which activates transcription factor NF- $\mathrm{B}$, causing pathological changes in gene expression $^{55}$. DHAP accumulation will stimulate synthesis of a -glycerol-P with consuming NADH. The a -glycerol-P reacting with fatty acid-CoA forms phosphatidate. The phosphatidate can further be dephosphorylated to produce DAG. DAG can activate the conventional PKC isoforms $(\alpha, \beta, \gamma)$ with calcium and activate novel PKC isoforms $(\delta, \varepsilon, \eta, \theta)$ without calcium $^{72,73}$. PKC isoforms $(\alpha, \beta, y)$. are up-regulated from the stage of cardiac hypertrophy extending to congestive heart failure, but PKC isoform $(\varepsilon)$ is up-regulated especially in cardiac hypertrophy and declines in congestive heart failure ${ }^{72}$. Hyperglycemia may activate PKC isoforms indirectly through 
both ligation of AGE receptors and the polyol pathway ${ }^{51}$. In addition, PKC pathway also can be activated by autocrine/paracrine factors such as TGF-beta, ET-1 and Ang $\|$ etc. $^{73}$

Activated PKCs have multiple adverse effects in diabetes, such as cardiac hypertrophy ${ }^{73,91}$. For example, transgenic mice with an increased number of L-type calcium channels and PKCa activation develop cardiac hypertrophy and severe cardiac dysfunction ${ }^{82}$; cardiac specific overexpression of $\mathrm{PKC} \beta_{2}$ isoform can cause cardiac hypertrophy, fibrosis and contractile dysfunction. The mechanism by which $P K C \beta_{2}$ damages contractile function of heart is that $\mathrm{PKC} \beta_{2}$ decreases cardiomyocyte calcium sensitivity by phosphorylating troponin $1^{95}$. Activation of the PKC $\varepsilon$ isoform may lead to compensated ventricular hypertrophy ${ }^{82.92}$. Elevated PKC $\delta$ can trigger cardiomyocyte apoptosis and necrosis by reducing ATP generation through inhibition of $\mathrm{PDH}$, increasing ROS generation and increasing cytochrome C release ${ }^{56}$.

Therefore, in Mb and Mk mice, the PKC pathway could be activated by ROS, hexosamine pathway, DAG and AGEs respectively or together. The activated PKC pathway could result in necrosis and apoptosis of cardiomyocytes, with results of cardiac dysfunction, hypertrophy and fibrosis.

\section{Cardiac remodeling in $\mathrm{Mb}$ and $\mathrm{Mk}$ mice}

In the heart, cardiac myocytes occupy $90 \%$ of the myocardial mass, whereas $90-95 \%$ of non cardiomyocytes are cardiac fibroblasts ${ }^{94}$. Cardiomyoctyes and non cardiomyoctyes are scaffolded by a network of fibrillar collagen. Based on morphology, the network can be subdivided into 
three components: epimysium, perimysium and endomysium. The epimysium surrounds the surfaces of the endocardial and the epicardial myocardium, providing the support for endothelial and mesothelial cells. The perimysium circles groups of muscle fibers and the endomysium, extended from perimysium, surrounds individual fibers ${ }^{87}$. Fibrosis tissues can be divided into three groups: perivascular fibrosis, interstitial fibrosis and microscopic scarring ${ }^{69}$. Collagen is a stable protein whose synthesis and degradation is normally slow (estimated to be $80-120$ days) and is regulated by cardiac fibroblasts ${ }^{62}$.

Under pathological conditions both the synthesis and degradation of collagens are altered, and the accumulation of collagen results in fibrosis. In morphologic terms, fibrosis can be classified as reactive fibrosis e.g., an adverse accumulation of perimysial collagen, or as reparative fibrosis, which fill in the empty space due to the death of cardiomyocytes for maintaining the structural integrity of myocardium ${ }^{53,69,85}$. Depending upon its location and magnitude, collagen fiber crosslinking, and relative abundance of type I and III collagens, fibrosis can adversely increase myocardial stiffness, leading to diastolic heart failure $(\mathrm{DHF})^{85}$. In patients with hypertension, Extracellular matrix $(E C M)$ accumulation is associated with left ventricular hypertrophy (LVH) and diastolic dysfunction and increases in ECM degradation seem to precede the transition to systolic failure ${ }^{85}$. In animal models of hypertensive heart disease (HHD), an increase in interstitial collagen (accumulated perimysium) is associated with diastolic heart failure, whereas degradation of endomysial and perimysial components of the collagen scaffolding is accompanied by ventricular dilatation and systolic heart failure ${ }^{54}$. Both 
intracellular and extracellular factors are involved in the remodeling process (collagen synthesis and degradation). One component in this remodeling process is a family of proteins called extracellular matrix degrading enzymes, the matrix metalloproteinases (MMPs), another is a family of proteins called tissue inhibitors of metalloproteinases (TIMPs). MMPs can degrade ECM proteins with differing degrees of specificity, the collagenases (MMP1, MMP8, and MMP13) initiate the ECM degradation process by cleaving the $\alpha$-chains of type I and type II collagens and the gelatinases (MMP2 and MMP9) further process the collagen fragments ${ }^{88}$. The actual activity of MMPs depends critically on the balance between active enzyme and TIMPs. TIMPs are multifunctional proteins that can inhibit the catalytic activity of MMPs, thus maintaining ECM homeostasis, for an example, TIMP-1 is a glycosylated protein and is secreted in a soluble form, forming 1:1 complex with MMP-9 ${ }^{74}$, 78. A disordered balance of MMP and TIMP activity in HHD can exert profound effects on cardiac function. For an example, the expression of MMP-1 and TIMP-1 in cardiomyocytes is not found in normotensive subjects but observed in heart failure hypertensive patients, furthermore, patients with diastolic heart failure (DHF) exhibit low grades of MMP-1 expression and patients with systolic heart failure (SHF) patients exhibit high grades of MMP-1 expression. No differences in cardiomyocyte TIMP-1 expression were observed between the two groups of patients. The expression of MMP-1 and TIMP-1 in interstitial matrix is found among the three groups of people: normal, DHF and SHF. However, the number of patients with high grades of interstitial MMP-1 expression in SHF group are more than that in DHF group. In contrast, the number of patients with high grades of Interstitial 
TIMP-1 expression in DHF are more than that in SHF group ${ }^{75}$. In addition, MMP activation can contribute to the fibrotic process by participating in a vicious circle in which ECM degradation promotes ECM protein synthesis and fibrosis. This pathway is particularly detrimental because MMP can degrade the native ECM very easily and the newly synthesized ECM which usually are oxidized and highly cross linked collagen are difficult to be degraded, favoring the accumulation of a much stiffer collagen ${ }^{53}$.

Myofibroblasts, converted from fibroblasts, are responsible for the synthesis of collagen and regulate collagen degradation through modifying the balance of MMPs and their inhibitors (TIMPs). Myofibroblasts are defined by their dual functions: fibroblast-like in terms of ECM synthesis and smooth muscle myocyte-like in terms of migration. Myofibroblast formation is controlled by growth factors, cytokines, and mechanical stimuli. Key hormones and cytokines for this transition are ANG II, ET-1, and TGF-beta ${ }^{53}$, 79. Myofibroblast-mediated collagen turnover is regulated by autocrine and paracrine factors generated within the myocardium and by endocrine hormones derived from the circulation such as ET-1, Ang II, TGF-beta and PAI- $1^{85,87,94}$. Taken together, these factors, which can be synthesized and secreted by cardiomyocytes ${ }^{58}, 68,83,89,90$, stimulate cardiac fibroblast conversion to myofibroblast and regulate myofibroblast mediated collagen turnover through modifying the balance of MMPs and TIMPS.

In cardiac specific lipoprotein lipase knock-out mice (hLPLO), fatty acid utilization decreases and glucoses oxidation increase. The decreased fatty acid utilization results in cardiac dysfunction such as diminished ejection fraction and extensive fibrosis although glucose oxidation is increased, 
furthermore, expression of some genes associated with cardiac fibrosis and matrix remodeling is increased such as TGF-beta, connective tissue growth factor, TIMP-1, MMP-2 and pro-collagen $1^{52}$. The decreased fatty acid utilization and increased glucose oxidation are similar to that in Mk mice, presumably Mk mice with hypertrophy and enhanced fibrosis should accompany with same gene expression pattern as hLPLO mice in which TGF-beta, connective tissue growth factor, TIMP-1, MMP-2 and pro-collagen 1 expression are upregulated.

In $\mathrm{Mb}$ mice, the hexosamine pathway modification of the $\mathrm{Sp} 1$ transcription factor by O-GICNAcylation may increase the synthesis and secretion of PAI-1 and TGF-beta, and high oxidative stress (ROS) could activate NF-kB and AP-1 transcriptional factors. In Mk mice, elevated glycolysis may increase ET-1 synthesis and secretion from cardiomyocytes, and AGEs and DAG activate PKC pathway. PKC pathway activation would turn on very complicated signal networks, such as increase of expression of PAl-1, TGF-beta, NF-kB and AP-1 etc. These transcription factors mentioned above could differentially regulate MMPs and TIMPs expression by binding to the genes' promoter region, e.g. Sp1 for TIMP-1, TIMP-2, TIMP-3,TIMP-4 and MMP-2, MMP-9 and MT1-MMP; Ap-1 for MMPs, TIMP-1 and TIMP-2; Ets for MMPs and TIMP-4; SMAD from TGF-beta for MMP-1, MMP-7, MMP-13 and MT1-MMP; NF-kB for MMPs ${ }^{59,88}$.

Plasminogen activator inhibitor-1 $(\mathrm{PAl}-1)$ is the major inhibitor of tissue and urokinase plasminogen activators and thereby reduces the conversion of plasminogen to plasmin, an extracellular protease that mediates fibrinolysis and activates matrix metalloproteinases ${ }^{58}$. Reduction of 
plasmin in tissues will decrease the activation of MMPs, favoring collagen accumulation. An elevated level of PAI-1 occurring in diabetes, insulin resistance, obesity, and hypertension has been ascribed to be a risk factor for development of cardiovascular disease ${ }^{64,70,76,80}$. In Mb mice, possible increased PAI-1 secretion could inhibit plasmin formation and reduce the activities of MMPs. In addition, increased Sp1 activity may also raise the expression of TIMP-1, TIMP-2, TIMP-3, TIMP-4, MMP-2, MMP-9 and MT1-MMP, disrupting the normal balance of MMPs and TIMPs. Therefore, O-GICNAC Sp1 may be regarded as a very important factor involved in the pathogenesis of $\mathrm{Mb}$ transgenic hearts.

Endothelin (ET)-1, a potent vasoconstrictor peptide from vascular endothelial cells, is also synthesized and secreted by cardiomyocytes and induces hypertrophy of cardiomyocytes ${ }^{68,77}$. The pattern of gene expression of ET-1 reflects the level of the glycolytic system in cardiomyocytes. Enhanced glycolysis will upregulate the cardiac gene expression of ET-1 ${ }^{59,71}$. In Mk mice, high glycolysis may upregulate ET-1 expression. The upregulated ET-1 may increase the expression of TIMP4 and MMPs, affecting the balance of TIMPs with MMPs.

TGF-beta expression is increased in the patients with left ventricular hypertrophy and dilated cardiornyopathy. Overexpression of TGF-beta transgenic mice demonstrates that TGF-beta can induce cardiac hypertrophy ${ }^{59,} 90$. The mechanism by which TGF-beta causes cardiac dysfunction is that TGF-beta stimulates fibroblast proliferation and conversion to myofibroblasts, and that TGF-beta induces the production of ECM components through cardiac myofibroblasts and fibroblasts, and that 
TGF-beta can recruit smooth muscle cells, monocytes and fibroblasts and stimulate wound repair and ECM deposition ${ }^{93}$. The nuclear factor SMAD from TGF-beta stimulation can bind the promoter region of MMP-1, MMP-7, MMP-13 and MT1-MP genes ${ }^{88}$. Therefore in Mb and Mk mice, TGF-beta may be responsible for cardiac hypertrophy and fibrosis, probably through regulating the gene expression of MMP-1, MMP-7, MMP-13 and MT1-MP.

In addition, increased intracellular oxidative stress in $\mathrm{Mb}$ mice and PKC activation in Mk mice may affect the expression of several MMPs and TIMPs, leading to unbalance of collagen synthesis and degradation ${ }^{59}$.

\section{$\mathrm{F}-2,6-\mathrm{P}_{2}$ involved in pathology of $\mathrm{Mk}$ and $\mathrm{Mb}$ mice}

When cardiomyocytes were challenged by insulin in vitro, the signal of P-AKT produced in Mk and Mb cardiomyocytes was significantly higher than that of FVB control as shown in figure14, whereas the signals of P-4EBP1, P-GSK-3b and P-IR were similar among cardiomyocytes from $\mathrm{Mk}, \mathrm{Mb}$ and FVB control mice. Our data suggest that $\mathrm{F}-2,6-\mathrm{P}_{2}$ is involved in insulin signal pathway below P-IR and beyond P-AKT. Possibly some middle mediator between P-IR and P-AKT such as IRS-1/2 or PI3K may be affected by F-2,6- $\mathrm{P}_{2}$ directly or indirectly. The elevated P-AKT might be associated with cardiac hypertrophy and matrix remodeling because P-AKT can increase MMP-2 gene expression ${ }^{81}$. Cross talk between Ang II and the insulin signal pathways occurs on the mediator IRS1/2. Both Insulin and Ang II stimulate the tyrosine phosphorylation of insulin receptor substrates (IRS). IRS proteins act as docking proteins for phosphatidylinositol 3-kinase (PI3-kinase) and growth factor receptor-binding protein 2 (Grb-2), followed by signaling P-AKT from 
PI3-kinase or MAPKs from Grb-2 ${ }^{57}$. F-2,6-P 2 could intensify the insulin signal by elevating P-AKT. Possibly F-2,6-P2 can also intensify the Ang II signals, which are associated with cardiac hypertrophy.

$\mathrm{F}-2,6-\mathrm{P}_{2}$ not only regulates glucose metabolisms by allosteric effects on PFK-1 but also regulates expression of key enzymes and transcriptional factors. For example, when levels of $\mathrm{F}-2,6-\mathrm{P}_{2}$ are elevated in the liver, glucose kinase (GK) expression is increased, whereas glucose-6-phosphotase (G6Pase), acetyl-CoA carboxylase( ACC) and fatty acid synthase ( FAS) expression are reduced ${ }^{47}$. Also affected as the expression of some transcriptional factors are, such as reduction of ChREBP, PPAR alpha, PGC-1 beta and SREBP ${ }^{47}$. ET-1 has been shown to significantly enlarge cardiomyocytes and PPARa activator inhibits ET-1-induced increases in cardiomyocyte size ${ }^{67}$. In Mk mice, high glycolysis may increase ET-1 secretion while high level of $F-2,6-P_{2}$ may decrease the expression of PPAR- $\alpha$. Therefore, high level of $\mathrm{F}-2,6-\mathrm{P}_{2}$ combined with increased secretion of ET-1 could be responsible for Mk cardiac hypertrophy.

In summary, it is probable that multiple pathways are involved in the observed hypertrophy and fibrosis of $\mathrm{Mk}$ and $\mathrm{Mb}$ mouse hearts. Transcriptional factors such as Sp1, Ap1, SMAD and autocrine/paracrine factors such as PAI-1, ET-1 and TGF-beta may be upregulated and/or activated, regulating the balance of MMPs with TIMPs and affecting collagen synthesis and degradation in $\mathrm{Mk}$ and $\mathrm{Mb}$ mice hearts. $\mathrm{F}-2,6-\mathrm{P}_{2}$ may be involved in the development of cardiac hypertrophy through Ang II signal pathway or decreasing the expression of PPARa gene directly or indirectly. 


\section{REFERENCE}

1. Friedman NE, Levitsky LL, Edidin DV, Vitullo DA, Lacina SJ and Chiemmongkoltip $P$. Echocardiographic evidence for impaired myocardial performance in children with type I diabetes mellitus. $1982 \mathrm{Am} \mathrm{J}$ Med. 73 : $846-850$

2. Kannel WB, Hjortland $M$ and Castelli WP. Role of diabetes in congestive heart failure: the Framingham study. 1974 Am J Cardiol 34(1):29-34.

3. Abbott RD, Donahue RP, Kannel WB and Wilson PW. The impact of diabetes on survival following myocardial infarction in men vs. women. The Framingham Study. 1988 JAMA 260(23):3456-3460.

4. Clark RJ, McDonough PM, Swanson E, Trost SU, Suzuki M, Fukuda M and Dillmann $\mathrm{WH}$. Diabetes and the accompanying hyperglycemia impairs cardiomyocyte calcium cycling through increased nuclear O-GICNAcylation. 2003 J Biol Chem. 278(45):44230-44237.

5. Gertz EW, Wisneski JA, Stanley WC and Neese RA. Myocardial substrate utilization during exercise in humans. Dual carbon-labeled carbohydrate isotope experiments. $1988 \mathrm{~J}$ Clin Invest 82: 2017-2025.

6. Neely JR, Rovetto MJ and Oram JF. Myocardial utilization of carbohydrate and lipids. 1972 Prog Cardiovasc Dis 15: 289-329.

7. Saddik M and Lopaschuk GD. Myocardial triglyceride turnover and contribution to energy substrate utilization in isolated working rat hearts. 1991 J Biol Chem 266: 8162-8170.

8. Atkinson LL, Fischer MA and Lopaschuk GD. Leptin activates cardiac fatty acid oxidation independent of changes in the AMP-activated protein kinase-acetyl-CoA carboxylase-malonyl-CoA axis. $2002 \mathrm{~J}$ Biol Chem 277: 29424-29430.

9. King KL, Okere IC, Sharma N, Dyck JR, Reszko AE, McElfresh TA, Kerner J. Chandler MP, Lopaschuk GD and Stanley WC. Regulation of cardiac malonyl-COA content and fatty acid oxidation during increased cardiac power. 2005 Am J Physiol Heart Circ Physiol 289: H1033-H1037. 
10. Rodrigues $\mathrm{B}$, Cam MC and McNeill JH. Myocardial substrate metabolism: implications for diabetic cardiomyopathy. $1995 \mathrm{~J}$ Mol Cell Cardiol 27: 169-179.

11. Schonekess BO. Competition between lactate, and fatty acids as sources of ATP in the isolated working rat heart. $1997 \mathrm{~J} \mathrm{Mol} \mathrm{Cell} \mathrm{Cardiol} \mathrm{29:}$ $2725-2733$.

12. Stanley WC, Lopaschuk GD and McCormack JG. Regulation of energy substrate metabolism in the diabetic heart. 1997 Cardiovasc Res 34: 25-33.

13. Barak $Y$, Nelson MC, Ong ES, Jones $Y Z$, Ruiz-Lozano $P$, Chien KR, Koder A and Evans RM. PPARgamma is required for placental, cardiac, and adipose tissue development. $1999 \mathrm{Mol}$ Cell 4: 585-595.

14. Young ME, McNulty $\mathrm{P}$ and Taegtmeyer $\mathrm{H}$. Adaptation and maladaptation of the heart in diabetes: Part II: potential mechanisms. 2002 Circulation 105: $1861-1870$.

15.An D and Rodrigues B. Role of changes in cardiac metabolism in development of diabetic cardiomyopathy. 2006 Am J Physiol Heart Circ Physiol. 291(4):H1489-H1506.

16. Ghosh S, An D, Pulinilkunnil T, Qi D, Lau HC, Abrahani A, Innis SM and Rodrigues $\mathrm{B}$. Role of dietary fatty acids and acute hyperglycemia in modulating cardiac cell death. 2004 Nutrition 20: 916-923.

17. Chatham JC and Forder JR. Relationship between cardiac function and substrate oxidation in hearts of diabetic rats. 1997 Am J Physiol Heart Circ Physiol 273: H52-H58.

18. Nicholl TA, Lopaschuk GD and McNeill JH. Effects of free fatty acids and dichloroacetate on isolated working diabetic rat heart. $1991 \mathrm{Am} J$ Physiol Heart Circ Physiol 261: H1053--H1059.

19. Wall SR and Lopaschuk GD. Glucose oxidation rates in fatty acid-perfused isolated working hearts from diabetic rats. 1989 Biochim Biophys Acta 1006: 97-103.

20. Kudo N, Barr AJ, Barr RL, Desai S and Lopaschuk GD. High rates of fatty acid oxidation during reperfusion of ischemic hearts are associated with a decrease in malonyl-CoA levels due to an increase in 5'-AMP-activated protein kinase inhibition of acetyl-CoA carboxylase. $1995 \mathrm{~J}$ Biol Chem 270: $17513-17520$.

21. Luiken JJ, Coort SL, Koonen DP, van der Horst DJ, Bonen A, Zorzano A and Glatz JF. Regulation of cardiac long-chain fatty acid and glucose uptake by translocation of substrate transporters. 2004 Pflügers Arch 448: 
$1-15$.

22. Pessin JE and Bell GI. Mammalian facilitative glucose transporter family: structure and molecular regulation. 1992 Annu Rev Physiol 54: 911-930.

23. Entman ML, Bornet EP, Van Winkle WB, Goldstein MA and Schwartz A. Association of glycogenolysis with cardiac sarcoplasmic reticulum: Effect of glycogen depletion, deoxycholate solubilization and cardiac ischemia: evidence for a phorphorylase kinase membrane complex. $1977 \mathrm{~J} \mathrm{Mol} \mathrm{Cell}$ Cardiol 9: 515-528.

24. Stanley WC, Recchia FA and Lopaschuk GD. Myocardial substrate metabolism in the normal and failing heart. 2005 Physiol Rev 85: 1093-1129.

25. Weiss JN and Lamp ST. Glycolysis preferentially inhibits ATP-sensitive $\mathrm{K}+$ channels in isolated guinea pig cardiac myocytes. 1987 Science 238: 67-69.

26. Wu C, Okar DA, Newgard CB and Lange AJ. Increasing fructose 2,6-bisphosphate overcomes hepatic insulin resistance of type 2 diabetes. 2002 Am J Physiol Endocrinol Metab. 282(1):E38-45.

27.Wu C, Okar DA, Newgard CB and Lange AJ. Overexpression of 6-phosphofructo-2-kinase/fructose-2, 6-bisphosphatase in mouse liver lowers blood glucose by suppressing hepatic glucose production. $2001 \mathrm{~J}$ Clin Invest. 107(1):91-98.

28. Choi IY, Wu C, Okar DA, Lange AJ and Gruetter R. Elucidation of the role of fructose 2,6-bisphosphate in the regulation of glucose fluxes in mice using in vivo ${ }^{13} \mathrm{C}$ NMR measurements of hepatic carbohydrate metabolism. 2002 Eur J Biochem. 269(18):4418-4426.

29. Kiss $L$ and Szabo $C$. The pathogenesis of diabetic complications: the role of DNA injury and poly(ADP-ribose) polymerase activation in peroxynitrite-mediated cytotoxicity. 2005 Mem Inst Oswaldo Cruz. 100 Suppl 1:29-37.

30. Davidoff AJ. Convergence of glucose- and fatty acid-induced abnormal myocardial excitation-contraction coupling and insulin signalling. 2006 Clin Exp Pharmacol Physiol. 33(1-2):152-158.

31. Luiken JJ, Schaap FG, van Nieuwenhoven FA, van der Vusse GJ, Bonen A and Glatz JF. Cellular fatty acid transport in heart and skeletal muscle as facilitated by proteins. 1999 Lipids 34, Suppl: S169--S175.

32. Saddik M and Lopaschuk GD. Myocardial triglyceride turnover and contribution to energy substrate utilization in isolated working rat hearts. 1991 J Biol Chem 266: 8162-8170. 
33. Chiu HC, Kovacs A, Blanton RM, Han X, Courtois M, Weinheimer CJ, Yamada KA, Brunet S, Xu H, Nerbonne JM, Welch MJ Fettig NM, Sharp TL, Sambandam N, Olson KM, Ory DS and Schaffer JE. Transgenic expression of fatty acid transport protein 1 in the heart causes lipotoxic cardiomyopathy. 2005 Circ Res 96: 225-233.

34. Chiu HC, Kovacs A, Ford DA, Hsu FF, Garcia R, Herrero P, Saffitz JE and Schaffer JEA. novel mouse model of lipotoxic cardiomyopathy. $2001 \mathrm{~J}$ Clin Invest 107: 813-822.

35. Yagyu H, Chen G, Yokoyama M, Hirata K, Augustus A, Kako Y, Seo T, Hu $Y$, Lutz EP, Merkel M, Bensadoun A, Homma $S$ and Goldberg IJ. Lipoprotein lipase (LpL) on the surface of cardiomyocytes increases lipid uptake and produces a cardiomyopathy. $2003 \mathrm{~J}$ Clin Invest 111: 419-426.

36. Christoffersen C, Bollano E, Lindegaard ML, Bartels ED, Goetze JP, Andersen $\mathrm{CB}$ and Nielsen LB. Cardiac lipid accumulation associated with diastolic dysfunction in obese mice. 2003 Endocrinology 144: 3483-3490.

37. Sharma S, Adrogue JV, Golfman L, Uray I, Lemm J, Youker K, Noon GP, Frazier $\mathrm{OH}$ and Taegtmeyer $\mathrm{H}$. Intramyocardial lipid accumulation in the failing human heart resembles the lipotoxic rat heart. 2004 FASEB J 18: 1692-1700.

38. Zhou YT, Grayburn P, Karim A, Shimabukuro M, Higa M, Baetens D, Orci $\mathrm{L}$ and Unger $\mathrm{RH}$. Lipotoxic heart disease in obese rats: implications for human obesity. 2000 Proc Natl Acad Sci USA 97: 1784-1789.

39. Chavez JA, Knotts TA, Wang LP, Li G, Dobrowsky RT, Florant GL and Summers SAA. Role for ceramide, but not diacylglycerol, in the antagonism of insulin signal transduction by saturated fatty acids. $2003 \mathrm{~J}$ Biol Chem 278: 10297-10303.

40. Itani SI, Ruderman NB, Schmieder F and Boden G. Lipid-induced insulin resistance in human muscle is associated with changes in diacylglycerol, protein kinase C and IkappaB-alpha. 2002 Diabetes 51: 2005-2011.

41. Kim JK, Fillmore JJ, Chen Y, Yu C, Moore IK, Pypaert M, Lutz EP, Kako Y, Velez-Carrasco W, Goldberg IJ, Breslow JL and Shulman GI. Tissue-specific overexpression of lipoprotein lipase causes tissue-specific insulin resistance. 2001 Proc Natl Acad Sci USA 98: $7522-7527$.

42. Kim JK, Fillmore JJ, Sunshine MJ, Albrecht B, Higashimori T, Kim DW, Liu ZX, Soos TJ, Cline GW, O'Brien WR, Littman DR and Shulman GI. PKC theta knockout mice are protected from fat-induced insulin resistance. $2004 \mathrm{~J}$ Clin Invest 114: 823-827.

43. Yuan M, Konstantopoulos N, Lee J, Hansen L, Li ZW, Karin M, and 
Shoelson SE. Reversal of obesity- and diet-induced insulin resistance with salicylates or targeted disruption of Ikkbeta. 2001 Science 293: 1673-1677.

44. Randle PJ. Regulatory interactions between lipids and carbohydrates: the glucose fatty acid cycle after 35 years. 1998 Diabetes Metab Rev. 14(4):263-283.

45. Belke DD, Larsen TS, Gibbs EM and Severson DL. Altered metabolism causes cardiac dysfunction in perfused hearts from diabetic $(\mathrm{db} / \mathrm{db})$ mice. 2000 Am J Physiol Endocrinol Metab. 279(5):E1104-1113.

46. Panagia M, Gibbons GF, Radda GK and Clarke K. PPAR alpha activation required for decreased glucose uptake and increased susceptibility to injury during ischemia. 2005 Am J Physiol Heart Circ Physiol 288: H2677-H2683.

47. Wu C, Khan SA, Peng LJ and Lange AJ. Roles for fructose-2,6-bisphosphate in the control of fuel metabolism: beyond its allosteric effects on glycolytic and gluconeogenic enzymes. $2006 \mathrm{Adv}$ Enzyme Regul. 46:72-88.

49. Wu C, Khan SA, Peng LJ, Li H, Carmella SG and Lange AJ. Perturbation of glucose flux in the liver by decreasing $\mathrm{F}-2,6-\mathrm{P}_{2}$ levels causes hepatic insulin resistance and hyperglycemia. $2006 \mathrm{Am} J$ Physiol Endocrinol Metab. 291(3):E536-543.

48. Gibbs EM, Stock JL, McCoid SC, Stukenbrok HA, Pessin JE, Stevenson RW, Milici AJ and McNeish JD. Glycemic improvement in diabetic $\mathrm{db} / \mathrm{db}$ mice by overexpression of the human insulin-regulatable glucose transporter (GLUT4). 1995 J Clin Invest. 95(4):1512-1518.

50. Tian R and Abel ED. Responses of GLUT4-deficient hearts to ischemia underscore the importance of glycolysis. 2001 Circulation. 103(24):2961-6.

51. Asbun J, Villarreal FJ. The pathogenesis of myocardial fibrosis in the setting of diabetic cardiomyopathy. J Am Coll Cardiol 2006 Feb 21;47:693-700.

52. Augustus AS, Buchanan J, Park TS, et al. Loss of lipoprotein lipase-derived fatty acids leads to increased cardiac glucose metabolism and heart dysfunction. J Biol Chem 2006 Mar 31;281:8716-8723.

53. Berk BC, Fujiwara K, Lehoux S. ECM remodeling in hypertensive heart disease. J Clin Invest 2007 Mar;117:568-575.

54. Briest W, Holzl A, Rassler B, Deten A, Baba HA, Zimmer HG. Significance of matrix metalloproteinases in norepinephrine-induced 
remodelling of rat hearts. Cardiovasc Res 2003 Feb;57:379-387.

55. Brownlee M. Biochemistry and molecular cell biology of diabetic complications. Nature 2001 Dec 13;414:813-820.

56. Budas GR, Churchill EN, Mochly-Rosen D. Cardioprotective mechanisms of PKC isozyme-selective activators and inhibitors in the treatment of ischemia-reperfusion injury. Pharmacol Res 2007 Jun;55:523-536.

57. Carvalheira JB, Calegari VC, Zecchin HG, et al. The cross-talk between angiotensin and insulin differentially affects phosphatidylinositol 3-kinase- and mitogen-activated protein kinase-mediated signaling in rat heart: implications for insulin resistance. Endocrinology 2003 Dec;144:5604-5614.

58. Chen HC, Bouchie JL, Perez AS, et al. Role of the angiotensin AT(1) receptor in rat aortic and cardiac PAI-1 gene expression. Arterioscler Thromb Vasc Biol 2000 Oct;20:2297-2302.

59. Deschamps AM, Spinale FG. Pathways of matrix metalloproteinase induction in heart failure: bioactive molecules and transcriptional regulation. Cardiovasc Res 2006 Feb 15;69:666-676.

60. Dhalla AK, Hill MF, Singal PK. Role of oxidative stress in transition of hypertrophy to heart failure. J Am Coll Cardiol 1996 Aug;28:506-514.

61. Du XL, Edelstein D, Rossetti L, et al. Hyperglycemia-induced mitochondrial superoxide overproduction activates the hexosamine pathway and induces plasminogen activator inhibitor- 1 expression by increasing Sp1 glycosylation. Proc Natl Acad Sci U S A 2000 Oct 24;97:12222-12226.

62. Eghbali M, Weber KT. Collagen and the myocardium: fibrillar structure, biosynthesis and degradation in relation to hypertrophy and its regression. Mol Cell Biochem 1990 Jul 17:96:1-14.

63. Eghbali M. Cardiac fibroblasts: function, regulation of gene expression, and phenotypic modulation. Basic Res Cardiol 1992;87 Suppl 2:183-189.

64. Erdem Y, Usalan C, Haznedaroglu IC, et al. Effects of angiotensin converting enzyme and angiotensin $\|$ receptor inhibition on impaired fibrinolysis in systemic hypertension. Am J Hypertens 1999 Nov;12:1071-1076.

65. Goldberg $\mathrm{HJ}$, Whiteside $\mathrm{Cl}$, Fantus IG. The hexosamine pathway regulates the plasminogen activator inhibitor-1 gene promoter and Sp1 transcriptional activation through protein kinase C-beta I and -delta. J Biol Chem 2002 Sep 13;277:33833-33841. 
66. Haltiwanger RS, Grove K, Philipsberg GA. Modulation of O-linked $\mathrm{N}$-acetylglucosamine levels on nuclear and cytoplasmic proteins in vivo using the peptide O-GICNAc-beta-N-acetylglucosaminidase inhibitor O-(2-acetamido-2-deoxy-D-glucopyranosylidene)amino-N-phenylcarba mate. J Biol Chem 1998 Feb 6;273:3611-3617.

67. Irukayama-Tomobe $Y$, Miyauchi T, Sakai S, et al. Endothelin-1-induced cardiac hypertrophy is inhibited by activation of peroxisome proliferator-activated receptor-alpha partly via blockade of c-Jun NH2-terminal kinase pathway. Circulation 2004 Feb 24;109:904-910.

68. Ito $\mathrm{H}$, Hirata $\mathrm{Y}$, Adachi $\mathrm{S}$, et al. Endothelin-1 is an autocrine/paracrine factor in the mechanism of angiotensin II-induced hypertrophy in cultured rat cardiomyocytes. J Clin Invest $1993 \mathrm{Jul} ; 92: 398-403$.

69. Janicki JS, Brower GL. The role of myocardial fibrillar collagen in ventricular remodeling and function. J Card Fail 2002 Dec;8:S319-S325.

70. Juhan-Vague I, Alessi MC, Vague P. Increased plasma plasminogen activator inhibitor 1 levels. A possible link between insulin resistance and atherothrombosis. Diabetologia $1991 \mathrm{Jul} ; 34: 457-462$.

71. Kakinuma Y, Miyauchi T, Suzuki T, et al. Enhancement of glycolysis in cardiomyocytes elevates endothelin-1 expression through the transcriptional factor hypoxia-inducible factor-1 alpha. Clin Sci (Lond) 2002 Aug;103 Suppl 48:210S-214S.

72. Koide $\mathrm{Y}$, Tamura K, Suzuki A, et al. Differential induction of protein kinase $\mathrm{C}$ isoforms at the cardiac hypertrophy stage and congestive heart failure stage in Dahl salt-sensitive rats. Hypertens Res 2003 May;26:421-426.

73. Koya D, King GL. Protein kinase $C$ activation and the development of diabetic complications. Diabetes 1998 Jun;47:859-866.

74. Kwak $\mathrm{HJ}$, Park $\mathrm{MJ}$, Cho $\mathrm{H}$, et al. Transforming growth factor-beta1 induces tissue inhibitor of metalloproteinase-1 expression via activation of extracellular signal-regulated kinase and Sp1 in human fibrosarcoma cells. Mol Cancer Res 2006 Mar;4:209-220.

75. Lopez B, Gonzalez A, Querejeta R, Larman M, Diez J. Alterations in the pattern of collagen deposition may contribute to the deterioration of systolic function in hypertensive patients with heart failure. J Am Coll Cardiol 2006 Jul 4;48:89-96.

76. McGill JB, Schneider DJ, Arfken CL, Lucore CL, Sobel BE. Factors responsible for impaired fibrinolysis in obese subjects and NIDDM patients. Diabetes 1994 Jan;43:104-109. 
77. Murray DB, Gardner JD, Brower GL, Janicki JS. Endothelin-1 mediates cardiac mast cell degranulation, matrix metalloproteinase activation, and myocardial remodeling in rats. Am J Physiol Heart Circ Physiol 2004 Nov;287:H2295-H2299.

78. Nagase $H$, Visse $R$, Murphy $G$. Structure and function of matrix metalloproteinases and TIMPs. Cardiovasc Res 2006 Feb 15;69:562-573.

79. Nishida $M$, Onohara N, Sato $Y$, et al. Galpha12/13-mediated up-regulation of TRPC6 negatively regulates endothelin-1-induced cardiac myofibroblast formation and collagen synthesis through nuclear factor of activated T cells activation. J Biol Chem 2007 Aug 10;282:23117-23128.

80. Poli KA, Tofler GH, Larson MG, et al. Association of blood pressure with fibrinolytic potential in the Framingham offspring population. Circulation 2000 Jan 25;101:264-269.

81. Risinger GM, Jr., Hunt TS, Updike DL, Bullen EC, Howard EW. Matrix metalloproteinase-2 expression by vascular smooth muscle cells is mediated by both stimulatory and inhibitory signals in response to growth factors. J Biol Chem 2006 Sep 8;281:25915-25925

82. Sabri A, Steinberg SF. Protein kinase $\mathrm{C}$ isoform-selective signals that lead to cardiac hypertrophy and the progression of heart failure. Mol Cell Biochem 2003 Sep;251:97-101.

83. Sadoshima J, Xu Y, Slayter HS, Izumo S. Autocrine release of angiotensin II mediates stretch-induced hypertrophy of cardiac myocytes in vitro. Cell 1993 Dec 3;75:977-984.

84. Shinohara M, Thornalley PJ, Giardino I, et al. Overexpression of glyoxalase-I in bovine endothelial cells inhibits intracellular advanced glycation endproduct formation and prevents hyperglycemia-induced increases in macromolecular endocytosis. J Clin Invest 1998 Mar $1 ; 101: 1142-1147$

85. Shirwany A, Weber KT. Extracellular matrix remodeling in hypertensive heart disease. J Am Coll Cardiol 2006 Jul 4;48:97-98.

86. Singh N, Dhalla AK, Seneviratne C, Singal PK. Oxidative stress and heart failure. Mol Cell Biochem 1995 Jun 7;147:77-81.

87. Spinale FG. Matrix metalloproteinases: regulation and dysregulation in the failing heart. Circ Res 2002 Mar 22;90:520-530.

88. Spinale FG. Myocardial matrix remodeling and the matrix metalloproteinases: influence on cardiac form and function. Physiol Rev 
89. Taimor G, Schluter KD, Frischkopf K, Flesch M, Rosenkranz S, Piper HM. Autocrine regulation of TGF beta expression in adult cardiomyocytes. J Mol Cell Cardiol 1999 Dec;31:2127-2136.

90. Taimor G, Schluter KD, Frischkopf K, Flesch M, Rosenkranz S, Piper $\mathrm{HM}$. Autocrine regulation of TGF beta expression in adult cardiomyocytes. J Mol Cell Cardiol 1999 Dec;31:2127-2136.

91. Takeishi Y, Jalili T, Ball NA, Walsh RA. Responses of cardiac protein kinase $C$ isoforms to distinct pathological stimuli are differentially regulated. Circ Res 1999 Aug 6;85:264-271.

92. Takeishi $Y$, Ping P, Bolli R, Kirkpatrick DL, Hoit BD, Walsh RA. Transgenic overexpression of constitutively active protein kinase $C$ epsilon causes concentric cardiac hypertrophy. Circ Res 2000 Jun 23;86:1218-1223.

93. Tomasek JJ, Gabbiani G, Hinz B, Chaponnier C, Brown RA. Myofibroblasts and mechano-regulation of connective tissue remodelling. Nat Rev Mol Cell Biol 2002 May;3:349-363.

94. van Wamel AJ, Ruwhof C, van der Valk-Kokshoom LE, Schrier PI, van der LA. The role of angiotensin II, endothelin-1 and transforming growth factor-beta as autocrine/paracrine mediators of stretch-induced cardiomyocyte hypertrophy. Mol Cell Biochem 2001 Feb;218:113-124.

95. Wakasaki H, Koya D, Schoen FJ, et al. Targeted overexpression of protein kinase $C$ beta2 isoform in myocardium causes cardiomyopathy. Proc Natl Acad Sci U S A 1997 Aug 19;94:9320-9325.

96. Yang X, Su K, Roos MD, Chang Q, Paterson AJ, Kudlow JE. O-linkage of $\mathrm{N}$-acetylglucosamine to $\mathrm{Sp} 1$ activation domain inhibits its transcriptional capability. Proc Natl Acad Sci U S A 2001 Jun 5;98:6611-6616.

97. Zhou YY, Wang SQ, Zhu WZ, Chruscinski A, Kobilka BK, Ziman B, Wang $\mathrm{S}$, Lakatta EG, Cheng $\mathrm{H}$, Xiao RP. Culture and adenoviral infection of adult mouse cardiac myocytes: methods for cellular genetic physiology. Am J Physiol Heart Circ Physiol. 2000 Jul;279(1):H429-36. 


\section{APPENDIX}

ACC acetyl-CoA carboxylase

ACS, acyl-CoA synthase

AGE, advanced glycolyation endproducts

$A K T$, protein kinase $B$

ANOVA, analyses of variance

AP-1, activating protein 1

aPK, atypical protein kinase

CAPP, ceramide-activated protein phosphatase

CAPK, ceramide-activated protein kinase

CD36, fatty acid translocase

ChREBP, carbohydrate response element -binding protein

CPT I, carnitine palmitoyltransferase I

DAG, diacylglycerol

$\mathrm{db} / \mathrm{db}$ mice, leptin receptor deficient mice

DHAP, dihydroxyacetone phosphate

DHF, diastolic heart failure

ECM, extracellular matrix

ET-1, endothelin -1,

Ets, E26 transformation-specific transcription factor

$\mathrm{F}-2,6-\mathrm{P}_{2}$, fructose-2,6-bisphosphate 
F-6-P, fructose-6-phosphate

FA, fatty acid

FAS, fatty acid synthetase,

FABPpm, fatty acid binding protein plasma membrane

FAT, fatty acid transporter

FATP, fatty acid transport protein

FFA, free fatty acids

G3P, glyceraldehyde-3-Phosphate

G6P, glucose -6- phosphate

G-6-P, glucose-6-phosphate

G6Pase, glucose-6-phosphotase

GAP, D-glyceraldehyde 3-phosphate

GAPDH, glyceraldehyde phosphate dehydrogenase

GFAT, glutamine:fructose-6-phosphate amino transferase

GK, glucose Kinase

GlcNAc, UDP-N-acetyl glucosamine

Glut1, glucose transporter 1

Glut4., glucose transporte 4

Grb-2, growth factor receptor-binding protein 2

GSH, glutathione

HE staining, hematoxylin-eosin staining

HHD, hypertensive heart disease

HK, hexokinase,

hLPLO, lipoprotein lipase knock-out mice

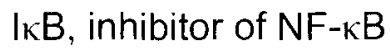


IRS, insulin receptor substrate

LPL, lipoprotein lipase

LVH, left ventricular hypertrophy

MAPKs, mitogen-activated protein kinases

MCD, malonyl-CoA decarboxylase

a-MHC, a-myosin heavy chain

$\beta-\mathrm{MHC}, \beta-\mathrm{myosin}$ heavy chain, ,

MMPs, matrix metalloproteinases

NADPH, nicotinamide adenine dinucleotide phosphate

NF-kB, nuclear factor-kappa B

PAI-1, plasminogen activator inhibitor-1

PARP, poly (ADP-ribose) polymerase

PBS, phosphate-buffered saline

PDC, pyruvate decarboxylase

$\mathrm{PDH}$, pyruvate dehydrogenase

PE, phenylephrine

PFK-1, phosphofructose kinase-1

PFK-2, phosphofructose kinase-2

PGC-1 beta, peroxisome proliferator-activated receptor gamma coactivator 1 beta

P-4EBP1, phosphorylation of eukaryotic translation initiation factor $4 \mathrm{E}$ binding protein 1

P-AKT, phospho-AKT

P-GSK-3b, phosphorylation of glycogen synthase kinase 3 beta

PIP3, phosphatidylinositol $(3,4,5)$ trisphosphate 
PI3K, phosphatidylinositol 3-kinase

P-IR, phospho insulin receptor

PKC, protein kinase C

PPAR- $\alpha$, peroxisome proliferator-activated receptor- $\alpha$

PS, penicillin-streptomycin

PTEN, phosphatase and tensin homologue deleted on chromosome 10

ROS, reactive oxygen species

SREBP, sterol-regulatory element-binding protein

SHF, systolic heart failure

Sp1, sequence-specific transcription factor 1

SMAD, mothers against decapentaplegic homolog

TCA cycle, citric acid cycle (Krebs cycle)

$\mathrm{Tg}$, triglycerides

TGF-beta, transforming growth factor beta

TIMPs, tissue inhibitors of metalloproteinases

$\mu \mathrm{U}$, microunit 


\section{CURRICULUM VITAE}

Name: Jianxun Wang

Address:

Department of Pharmacology \&Toxicology

University of Louisville School of Medicine

570 S. Preston Street

Louisville, KY 40202

Tel: $502-852-2650$

Email: [0wang02@louisville.edu

Date and place of Birth: June 12, 1969, China

Education:

9/1987--7/1991, B.S. in Biology, Lanzhou University

9/1991--7/1994, M.S. in Genetics, Sun Yat-sen University

8/2005--current, Graduate Student in Department of Pharmacology and Toxicology Ph.D program, University of Louisville

Awards:

8/2005--6/2007, Integrated Programs in Biomedical Sciences Predoctoral Fellowship

7/2007--6/2009, American Heart Association Predoctoral Fellowship

Publications:

1. Wang J, Song Y, Wang Q, Kralik PM, Epstein PN. Causes and characteristics of diabetic cardiomyopathy. Rev Diabet Stud. 2006 Fall;3(3):108-17. Epub 2006 Nov 10

2. Wang J, Song Y, Elsherif L, Song Z, Zhou G, Prabhu SD, Saari JT, Cai L. Cardiac metallothionein induction plays the major role in the prevention of diabetic cardiomyopathy by zinc supplementation.

Circulation. 2006 Jan 31;113(4):544-54. Epub 2006 Jan 23.

3. Song $Y$, Wang J, Li XK, Cai L. Zinc and the diabetic heart. 
4. Song Y, Wang J, Li Y, Du Y, Arteel GE, Saari JT, Kang YJ, Cai L.

Cardiac metallothionein synthesis in streptozotocin-induced diabetic mice, and its protection against diabetes-induced cardiac injury

Am J Pathol. 2005 Jul; 167(1):17-26.

5. Cai L, Wang J, Li Y, Sun X, Wang L, Zhou Z, Kang YJ. Inhibition of superoxide generation and associated nitrosative damage is involved in metallothionein prevention of diabetic cardiomyopathy. Diabetes. 2005 Jun;54(6): 1829-37.

6. Wang $Y$, Kodani E, Wang J, Zhang SX, Takano H, Tang XL, Bolli R. Cardioprotection during the final stage of the late phase of ischemic preconditioning is mediated by neuronal NO synthase in concert with cyclooxygenase-2. Circ Res. 2004 Jul 9;95(1):84-91. Epub 2004 May 27.

7. Wang Y, Guo Y, Zhang SX, Wu WJ, Wang J, Bao W, Bolli R. Ischemic preconditioning upregulates inducible nitric oxide synthase in cardiac myocyte. J Mol Cell Cardiol. 2002 Jan;34(1):5-15. 